\title{
Effect of Buckling Restrained Braces Locations on Seismic Responses of High-Rise RC Core Wall Buildings
}

\author{
Munir Ahmed, ${ }^{1}$ Shahzadi Tayyaba, ${ }^{2}$ and Muhammad Waseem Ashraf ${ }^{3}$ \\ ${ }^{1}$ Mohammad Ali Jinnah University, Islamabad 44000, Pakistan \\ ${ }^{2}$ The University of Lahore, Lahore 54000, Pakistan \\ ${ }^{3}$ GC University, Lahore 54000, Pakistan
}

Correspondence should be addressed to Munir Ahmed; dr.munir@jinnah.edu.pk

Received 4 June 2015; Revised 14 September 2015; Accepted 27 September 2015

Academic Editor: Marcello Vanali

Copyright (C) 2016 Munir Ahmed et al. This is an open access article distributed under the Creative Commons Attribution License, which permits unrestricted use, distribution, and reproduction in any medium, provided the original work is properly cited.

\begin{abstract}
Conventionally, a flexural plastic hinge is designed and detailed at the core wall base and coupling beams ends to control the seismic responses. This strategy is based on allowing the damage to be concentrated on main structural components. To avoid such damage, an alternative strategy using energy dissipating devices (EDDs) such as buckling restrained braces (BRBs) is being studied and implemented nowadays. In this study, effect of BRBs locations on forty- (40-) story high-rise RC core wall case study building has been studied in detail using Nonlinear Response History Analysis (NLRHA) for seven spectrally matched ground motions. BRBs have been installed at critical locations identified with respect to the maximum DBE elastic modal racking shear deformation demands and force (shear and moment) demands in three different options. The force, deformation, and energy demands on structural components are compared for conventional design and different options of BRBs. The comparison with conventional design shows that BRBs not only are effective for reducing shear force demand along wall height, bending moment demand at mid height, and deformation demands by $10 \%, 45 \%$, and $45 \%$, respectively, but significantly reduce the rotation and energy demands in the core wall by $90 \%$ and $250 \%$, respectively.
\end{abstract}

\section{Introduction}

High-rise reinforced-concrete (RC) core wall buildings are being built in areas of high seismic hazard. The structural system of these buildings is classified as building frame system as per Uniform Building Code [1]. For reasons of economy, less construction time, and flexible architecture, these systems are preferred over other lateral-force-resisting systems, for example, dual structural systems $[2,3]$. The core wall buildings consist of central core wall and peripheral columns connected by the posttensioned slabs at each story. Sometimes, core wall is also connected to the outer columns through one- or twostory deep outriggers to control the lateral displacements. The stiffness of the core wall is much higher than the combined stiffness of the peripheral columns. Therefore, lateral load is mostly resisted by the core wall. For both design basis earthquake (DBE) and the maximum considered earthquake (MCE) levels, it is uneconomical to design these walls in the elastic range. Under such severe shakings, flexural single plastic hinge ( $\mathrm{SPH})$ is designed and detailed at the core wall base and coupling beams ends to reduce the seismic demands. However, the plastic rotation in the hinge zone must be within an acceptable limit. The wall above the hinge zone and the other portion of coupling beams is expected to remain elastic [4-8].

Recent studies on a 60-story and 40-story RC core wall buildings with SPH at the base in high seismic areas show that the base shear demand at MCE level is as high as 15-20\% of the total building weight. Furthermore, bending moment demands at upper levels shall be almost double compared to that at the base level [9-11]. To address these large shear and moment demands, the design may not be economically justified for rare event of an MCE earthquake level. Furthermore, problem of reinforcement placing may arise due to reinforcement congestion. Therefore, these demands need to be reduced by different possible measures. 

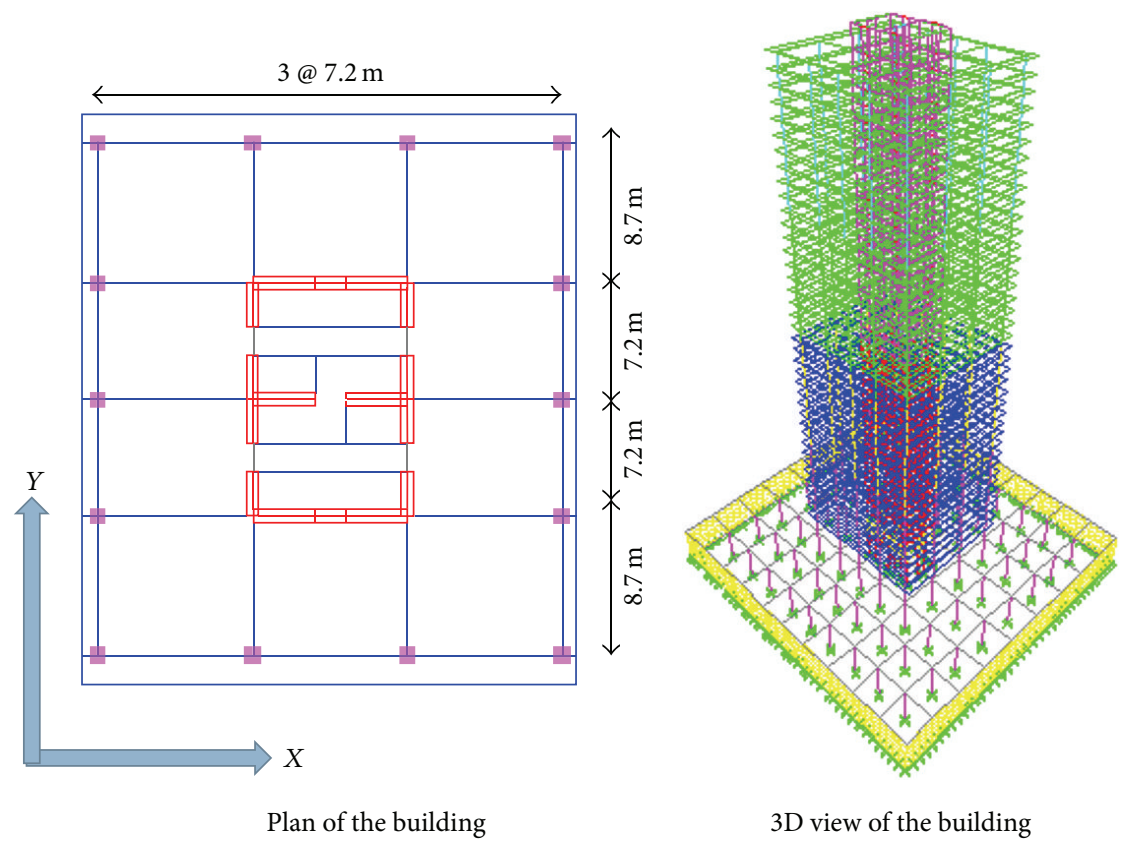

FIGURE 1: Plan and 3D model of the building.

Several approaches were proposed to reduce these demands. One approach is to allow the wall to yield at any location along its height. This approach is referred to as Ductile Wall (DW) approach and was proposed by [12]. This approach is uneconomical due to stringent ductile detailing requirements all along the wall height. Furthermore, these buildings may not be economically repairable due to spread of damage in a seismic event. The second approach is Dual Plastic Hinge (DPH) approach in which one hinge is allowed at mid height in addition to the plastic hinge at the base [13]. This approach is effective only for reduction of 2 nd mode bending moment demand at mid height of the wall. Another approach in which plastic hinges were allowed at several effective locations was proposed by [14-16].

However, in all the above-mentioned approaches, damage is allowed in main structural components such as shear walls and coupling beams. To avoid this, another strategy which incorporates energy dissipating devices (EDDs) in the structural system to reduce the inelastic energy dissipation demand on the framing system $[17,18]$ has been introduced. In this strategy the structural components may remain elastic or suffer less damage during an earthquake; the structural and nonstructural damage may be considerably reduced. These devices were incorporated in a number of new buildings and were used to retrofit existing buildings to reduce the wind and seismic induced responses [19, 20]. Buckling restrained braces (BRBs) are one of the proven choices as EDDs for reducing seismic response reduction. In Japan, BRBs have been used successfully for many projects in retrofitting of the existing buildings as well as design of new buildings. However in the United States (US), their use is reported in 30 buildings including retrofitting of the existing buildings and new construction [21, 22] (Black et al., 2004; Keten, 2006).
Their recent use in high-rise buildings is reported in a 60story One Rincon Hill Building in San Francisco [10] and 50story tall ductile core wall building in Philippines [23].

In this study, effect of BRBs locations on 40-story highrise $\mathrm{RC}$ core wall case study building is studied in detail using Nonlinear Response History Analysis (NLRHA). BRBs have been placed at critical locations in cut in shear walls and between peripheral columns and shear walls. The critical locations are identified based on DBE elastic racking shear deformation demands and force demands. The comparison between different options in terms of force (shear force and bending moment), deformation (displacement, racking shear deformation, and plastic hinge rotation in wall), and energy demands has been shown.

\section{The Case Study Building and Elastic Modal Demands}

2.1. Description of the Case Study Building. The building is taken from previous research studies [9-11, 14-16]. The typical floor plan of the building and 3D model are shown in Figure 1. This is a 40-story residential tower above the ground with three levels of below-grade parking. The typical story height is $3 \mathrm{~m}$ and a lobby-level height is $6 \mathrm{~m}$. Thus, the total height of building above ground is $120 \mathrm{~m}$. The building is supported by a thick foundation slab to transfer load on a firm ground. The soil condition beneath and surrounding the building is represented by stiff clay soil. This is equivalent to the soil type SD in the UBC-97 [1]. The structural components of the building are comprised of a central RC core wall thickness (750 mm TH up to Level 20 and $600 \mathrm{~mm}$ thick form Levels 21 to 40$), 14$ peripheral columns $(900 \mathrm{~mm} \times 900 \mathrm{~mm}$ up to Level 

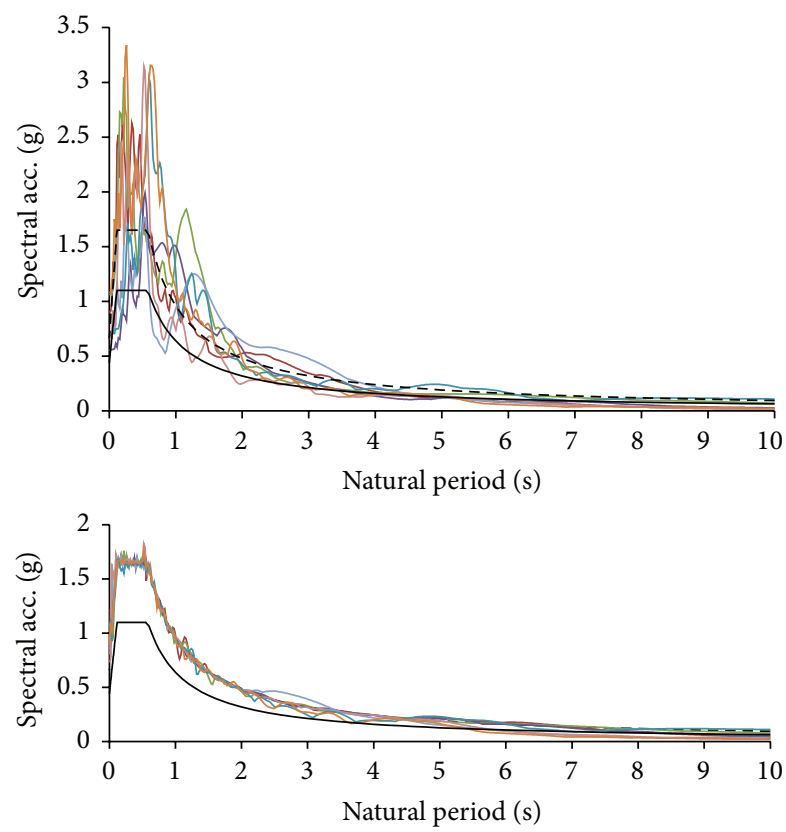

Response spectra of scaled ground motions

- SH-PR-360 $\times 3.0$

$-\mathrm{HM}-\mathrm{H}-090 \times 4.0$

- LP-HSP-000 $\times 1.5$

CM-EUR-090 $\times 4.0$

- Hon-MGH-EW $\times 4.0$

- Chichi-Taipei-090 06.0

Imp-Ch-012 $\times 4.0$

Target spectra

- DBE spectrum (UBC-97, zone 4, SD)

- - - MCE spectrum $($ DBE spectrum $\times 1.5)$

FIGURE 2: Comparison of the matched spectra of the ground motions with DBE and MCE spectra.

20 and $600 \mathrm{~mm} \times 600 \mathrm{~mm}$ from Level 21 to Level 40), and $200 \mathrm{~mm}$-thick posttensioned concrete flat slabs resting on the peripheral columns and the central core wall. There are door openings in the wall. These openings are covered by coupling beams. The size of coupling beams is $600 \mathrm{~mm} \times 1500 \mathrm{~mm}$ above lobby level and $750 \mathrm{~mm} \times 800 \mathrm{~mm}$ from Level 3 to Level 20 , whereas it is $600 \mathrm{~mm} \times 700 \mathrm{~mm}$ from Levels 21 to 40 . The compressive strength of concrete for columns and walls is set to $55 \mathrm{MPa}$ up to Level 20 and $42 \mathrm{MPa}$ from Level 20 to the roof. The reinforcing bars are Grade- 60 steel with specified yield strength of $420 \mathrm{MPa}$. The central core wall forms the lateral load resisting system, whereas posttensioned slabs and peripheral columns shall mainly form the gravity load resisting system. The gravity load includes self-weight of the structure, dead loads of $1.92 \mathrm{kN} / \mathrm{m}^{2}$, and live loads of $2.4 \mathrm{kN} /$ $\mathrm{m}^{2}$.

2.2. DBE Elastic Modal Demands by Modal Response Spectrum Analysis. The modal response spectrum analysis (MRSA) of the building is performed using UBC-97 [1] design basis response spectrum for seismic zone- 4 and soil type SD for $5 \%$ damping in the single mode of vibration. The response spectrum is shown in Figure 2. The building is analysed in the $X$-direction only for brevity and considered sufficient for the purpose of this study. The commercial software ETABS [24] is used for MRSA procedure. First six modes are found to be sufficient for $90 \%$ mass participation in the MRSA. However, results show that both shear and moment demands are mainly dominated by first four modes. The combined demands are obtained by combining individual modal demands using CQC method.

DBE elastic demands in the core wall in first four dominant modes as well as their combination are shown in Figures 3(a), 3(b), 3(c), and 3(d), respectively. Both shear and moment demands are dominated by 1st, 2nd, and 3rd mode, whereas deformation demands are dominated by the 1st mode only. These demands shall be used for preparation of model for Nonlinear Response History Analysis and to find the critical locations of the BRBs. The story racking deformation angle is the shear deformation of the panel between wall and peripheral columns. This is equal to the conventional story drift ratio subtracted by the floor inclination angle measured clockwise from a horizontal plane.

\section{Description of Model for Nonlinear Response History Analysis and Selection of Ground Motions}

The nonlinear model is implemented in Commercial Software Perform-3D [25]. The core wall is modelled using 22 one-story high $(3 \mathrm{~m})$ inelastic shear wall elements at the plastic hinge location at the base. Each shear wall element was comprised of 8 concrete and 8 steel fibres at the plastic hinge locations, whereas the wall at other locations is modelled as the 22 linear elastic shear wall elements. The previous studies $[26,27]$ show that plastic hinge length of the high-rise wall may be taken as $1 / 2$ to $2 / 3$ times wall length (Lw). The length of the wall in this case is $10 \mathrm{~m}$. Therefore, plastic hinges were allowed over two-story height $(6 \mathrm{~m})$, which is approximately $2 / 3$ Lw. However, one-story high inelastic shear wall elements were used over the plastic hinge length based on section 6.8.2.2.2 of FEMA-356 [28], which mentions that plastic hinge length should be smaller than one-story height or Lw/2.

The flexural strength at the plastic hinge location should be as low as possible to allow early yielding of the wall, but at the same time plastic hinge rotation as well as related deformation demands such as story drift and racking shear deformation should be within permissible limits. In this study, flexural strength is based on the DBE design moment demands determined by code based procedure of UBC-97 [1]. These are larger than the values obtained either (a) by dividing the combined elastic demands by appropriate response modification factor " $R$ " of 5.5 or (b) by dividing " $R$ " factor required to satisfy the requirement of $90 \%$ of the base shear obtained from static analysis procedure. There are mainly two reasons for setting flexural strength in this way: (1) this is based on the standard code based design such as UBC-97 [1]; (2) modern code such as LATBDC-2008 [29] recommend capacity design as a first step of the performance based design, and designers are using the code based design as the initial step and later 


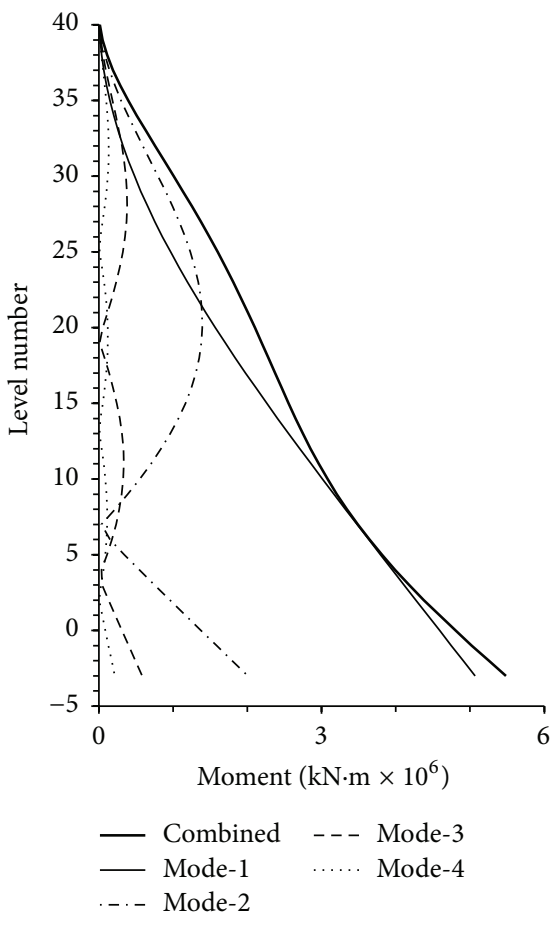

(a)

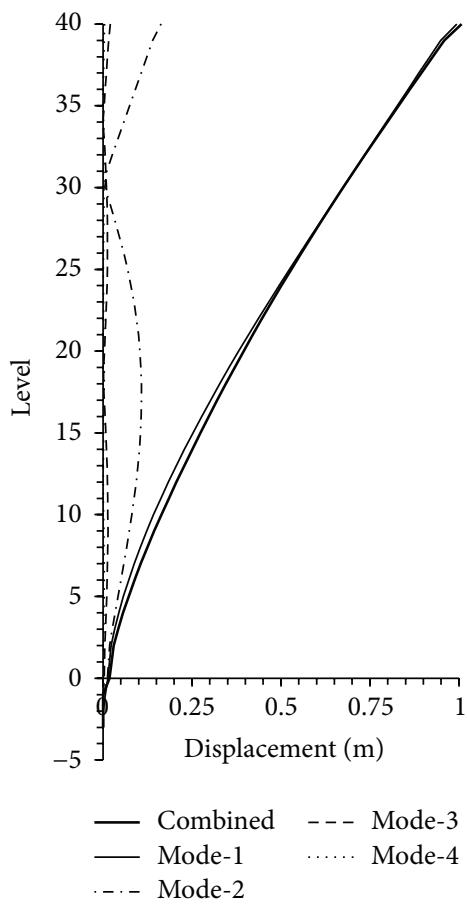

(c)

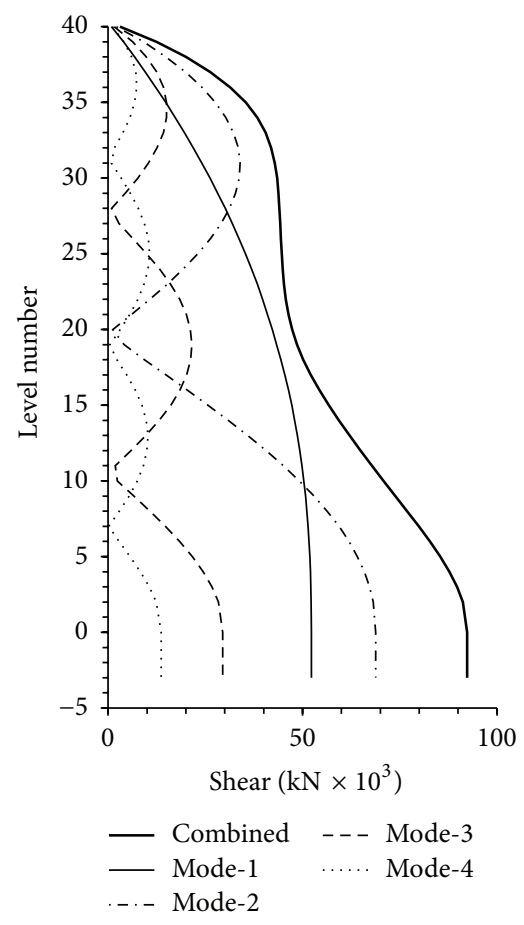

(b)

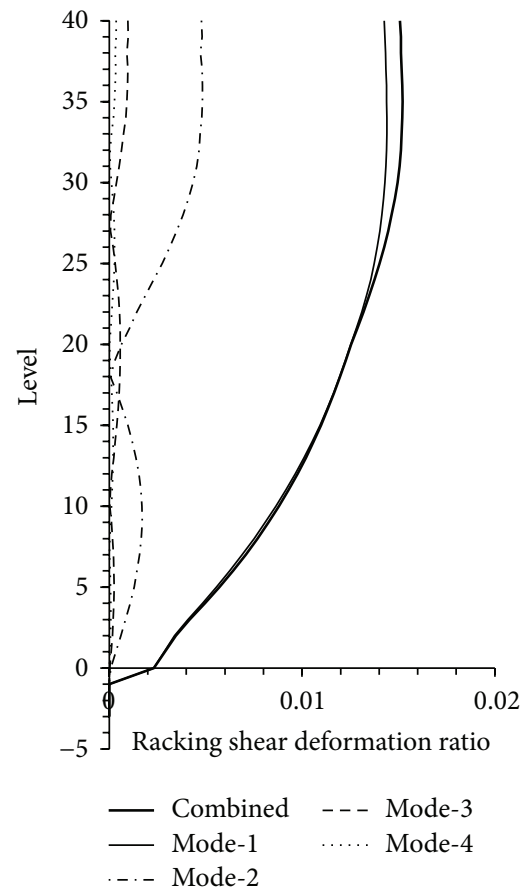

(d)

Figure 3: DBE elastic modal and total seismic demands. (a) Moment demands, (b) shear demands, (c) displacement demands, and (d) racking shear deformation demands.

confirm the performance at MCE level by the NLRHA procedure.

Plastic hinges are also induced at both ends of coupling beams. The characteristics of the plastic hinges are determined by beam cross section properties and flexural reinforcement worked out based on the design demands and assumed plastic hinge length of 0.5 times the depth of the beam. The remaining portion of the coupling beam is modelled as elastic beam element. A trilinear moment-curvature relationship without stiffness and strength degradation is 

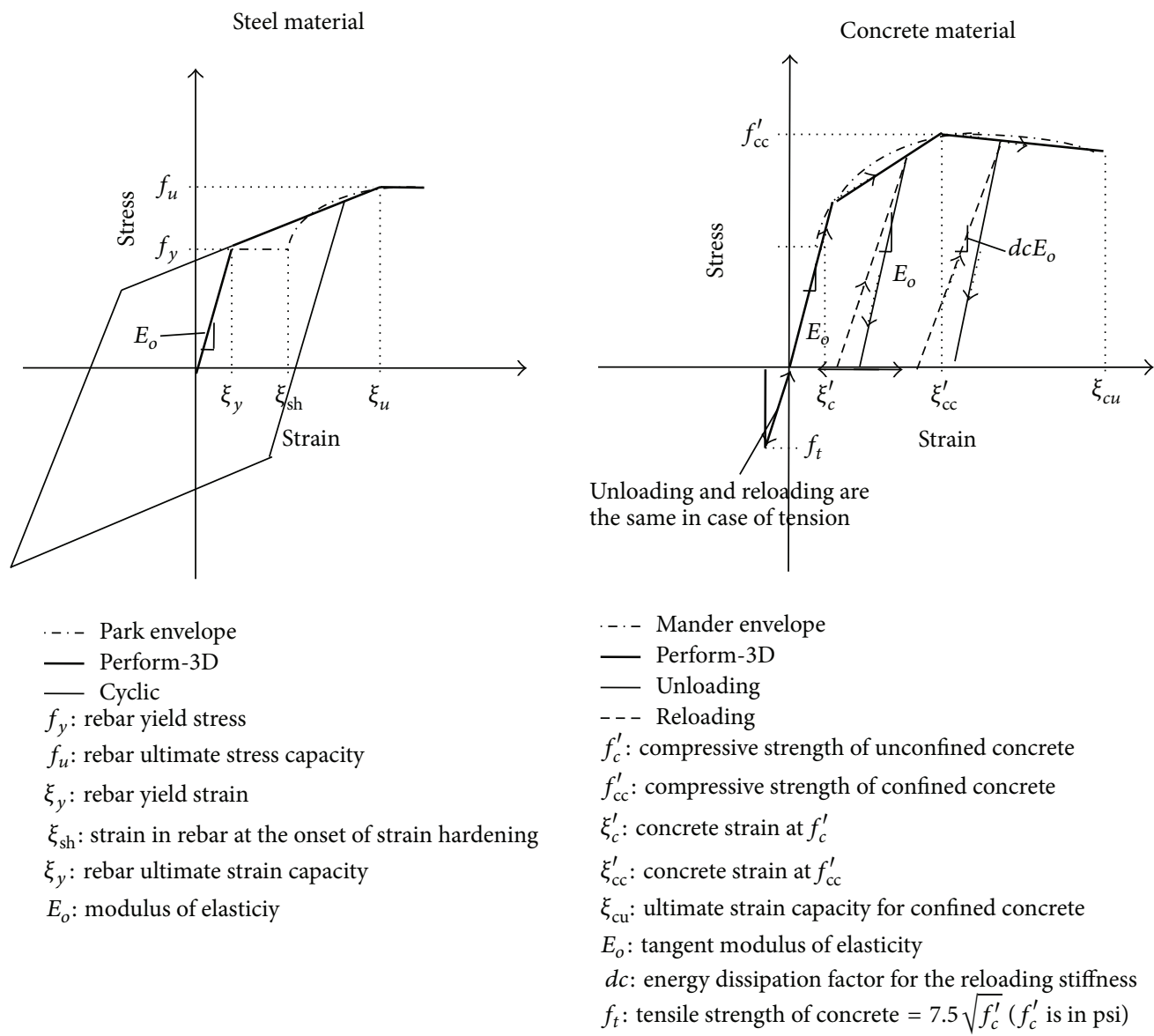

FIGURE 4: Nonlinear Park Steel and Mander's concrete model.

used for modelling plastic hinges at the ends of coupling beams. All slabs and columns are modelled by elastic slab and column elements of the Perform-3D, respectively.

Seven set of ground motions are selected from PEER [30] and COSMOS [31] data bases. The ground motions include both short distance moderate and long distance large magnitude earthquake. The selected ground motions are first roughly scaled up or down by a constant factor to approximately match the target MCE spectrum. The roughly scaled ground motions are then matched to the MCE target spectrum by using time domain spectral matching technique of [32]. The software RSP match [33] is used for this purpose. The target spectrum and spectra of seven spectrally matched time history used in this study are shown in Figure 2. Nonlinear material models similar to those proposed by [34] were assigned for rebar's and concrete material, respectively, as shown in Figure 4. The modal damping is set as per recommendations of [35], CTBUH (2008), and [36].

\section{Analysis of Structure without BRBs}

The controlled structure described in Section 3 is analysed for seven sets of ground motions. The shear and moment demands obtained are shown in Figure 5. These results show that base shear demand is about $15 \%$ of the total building weight. Similarly, moment demand is also very high at mid height. However at the base, the moment demand is clipped to the flexural strength of plastic hinge. If the wall is designed for mid height moment to remain elastic and hence no damage, there shall be reinforcement congestion. On the other hand, if plastic hinge is allowed at mid height, the core wall shall be subjected to high rotational demands and hence damage near the mid height of the wall in addition to the base. To reduce damage at the base of the wall as well as reduce mid height moment to avoid reinforcement congestion, an alternative strategy using different arrangements of buckling restrained braces (energy dissipating devices) has been evolved in the next section (Options-2-4) and results are compared with the controlled structure (Option-1).

\section{Buckling Restrained Braces, Evolvement of Strategies for Efficient Locations, Their Size, and Modelling}

5.1. Buckling Restrained Brace. An ordinary brace exhibits unstable hysteretic behaviour due to buckling in compression; hence it cannot dissipate much energy. To avoid compression buckling and to achieve more energy dissipation, another brace known as buckling restrained brace (BRB) has been introduced. This type of brace exhibits stable hysteric 


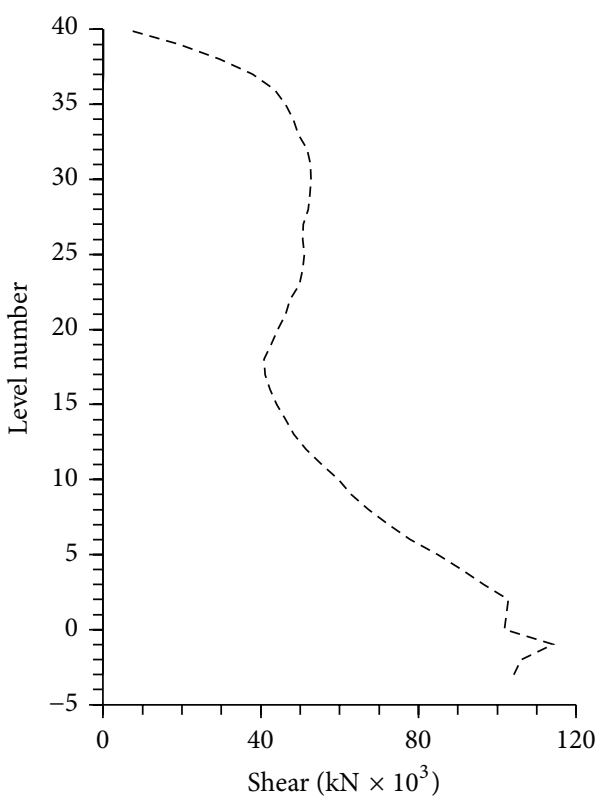

- - - Mean MCE demands

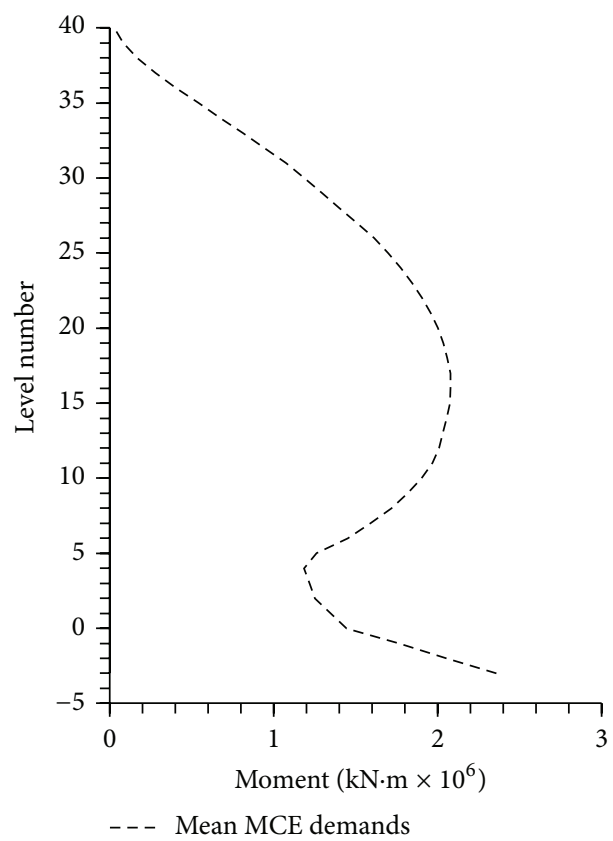

FIGURE 5: Inelastic MCE shear and moment demands in the controlled structure.
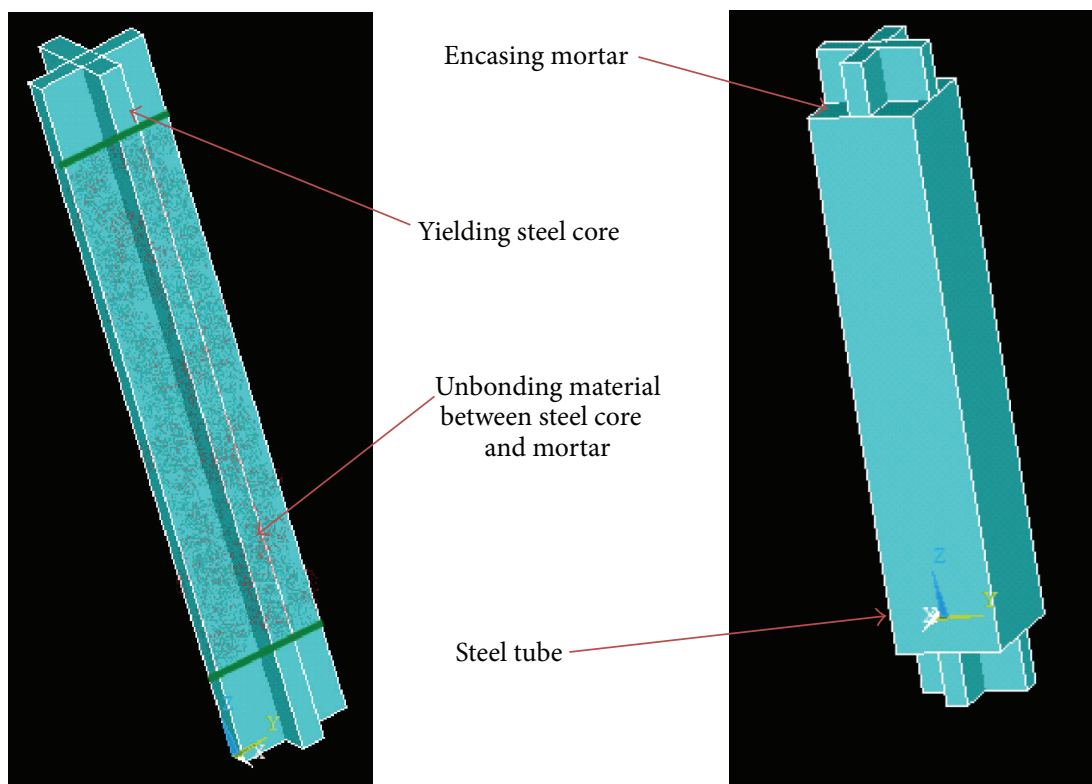

Figure 6: Typical BRB.

behaviour because its compression buckling is avoided due to encasing by an outer steel tube. The main brace and outer tube are separated by bonding material in order to accommodate the lateral expansion due to its compression yielding [37]. A typical BRB is shown in Figure 6 [38].

5.2. Location of Buckling Restrained Braces. BRBs have been installed at several critical locations based on the results of elastic modal decomposition analysis in dominant modes such as 1st, 2nd, and 3rd modes and results are compared with controlled structure described in Section 4 (Option-1). In second option (Option-2), the BRBs have been installed at bays 2, 3, and 4 between peripheral columns and central core wall based on the maximum racking shear deformation demands in 2nd and 3rd modes. This arrangement is shown in Figure 7. In third option, small size BRBs have also been installed at bays 2 and 4 in cut in central core wall at the maximum moment demands in 2 nd and $3 r$ modes. These BRBs are in addition to the BRBs in Option-2. This arrangement is shown in Figure 8. In final and fourth option (Option-4), BRBs have been installed in cut in central core wall at bays 2 and 4 at the location of maximum shear force in 2nd and 3rd modes in addition to the BRBs in Option-2. This is shown in Figure 9. It may be noted that the locations of BRBs in 

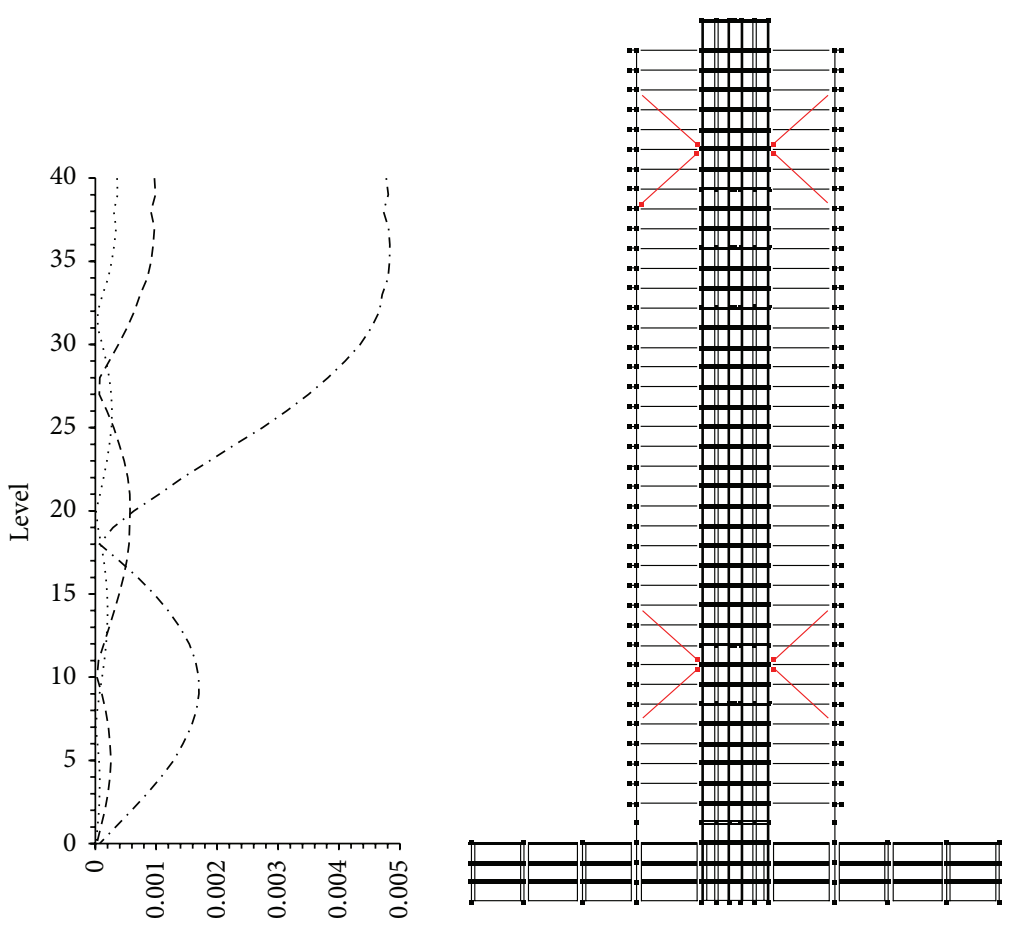

Racking shear deformation ratio

-.- Mode-2 …... Mode-4

FIGURE 7: Arrangement of the BRBs at locations of maximum racking shear deformation in exterior panels (Option-2).

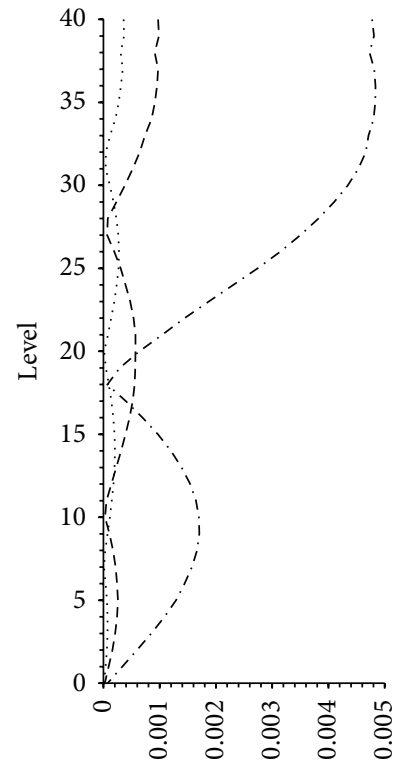

Racking shear deformation ratio

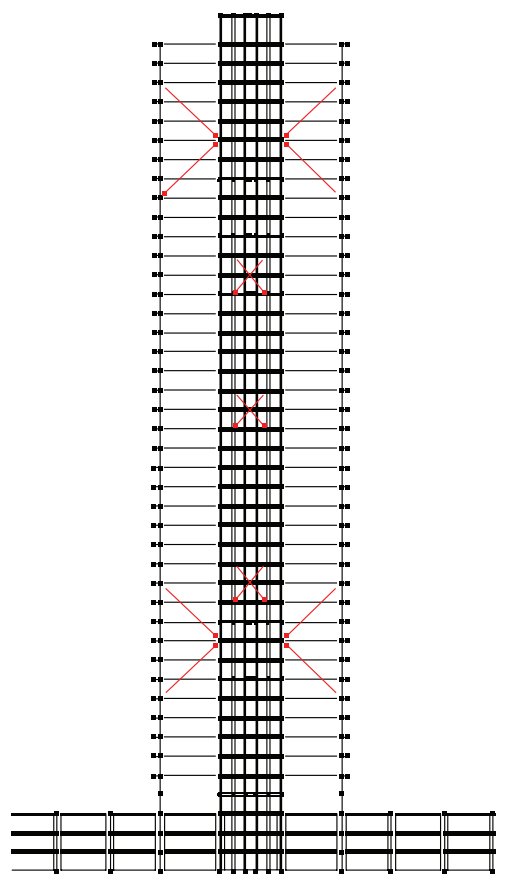

Mode-4

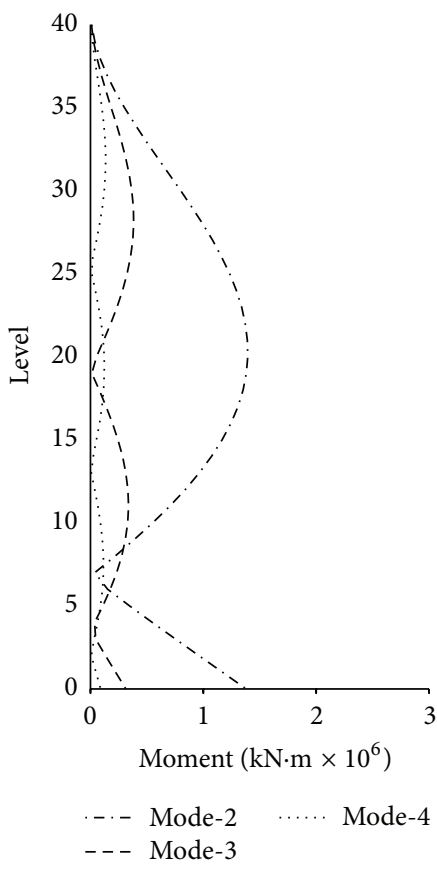

FIGURE 8: Arrangement of the exterior BRBs at locations of maximum DBE elastic racking shear deformation in 2nd and 3rd mode and interior BRBs at locations of maximum DBE elastic moment demands in 2nd and 3rd mode (Option-3). 


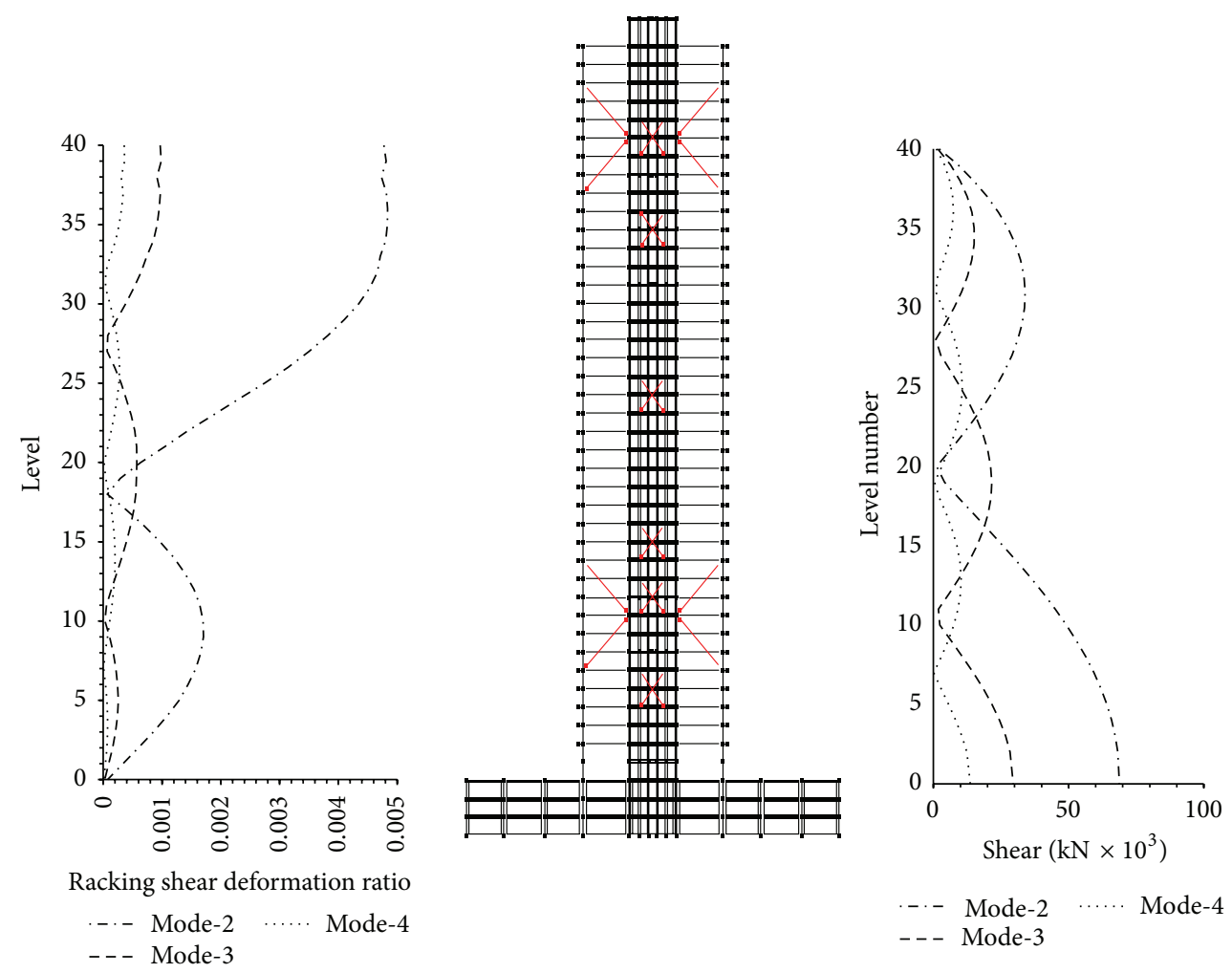

FIGURE 9: Arrangement of the exterior BRBs at locations of maximum DBE elastic racking shear deformation in 2nd and 3rd mode and interior BRBs at locations of maximum DBE elastic shear demands in 2nd and 3rd mode (Option-3).

Option-1, Option-2, and Option-3 are also suitable for mode1.

The BRBs dissipate energy through axial tension and compression. To achieve maximum energy dissipation, the BRBs should be placed at the proper locations and angles. Each BRB has been placed at an angle of approximately $\pi / 4$ covering almost three stories for exterior brace and two stories for brace in cut in core wall. These V-shaped BRBs configurations resemble the BRBs configuration used in mega braced frames steel buildings reported in the previous studies [39-41]. BRBs shall cross the slabs through purposely built openings provided in the slabs. A horizontal drag element is used from point, where BRB connects to the column, to the central core wall to take care of the horizontal force component of the BRB axial force at column connection.

5.3. Size of Buckling Restrained Braces. Sizes of the BRBs have been selected by hit and trial using more rigorous nonlinear time history analyses (NLTHAs) using displacement-based design approach. Their size should neither be too large to be uneconomical, nor be too small to be ineffective. The $X$ section of the braces between peripheral columns and central core wall is selected as $7500 \mathrm{~mm}^{2}$, whereas it is $3750 \mathrm{~mm}^{2}$, for braces in cuts in core wall. The buckling restrained braces manufactured by star seismic with normal yield strength of $280 \mathrm{MPa}$ are used for braces between peripheral columns and central core wall [42]. However, the low yield point-100 (LYP100) steel core manufactured by Nippon Steel Corporation, Japan, with specified yield strength of $100 \mathrm{MPa}$ is used

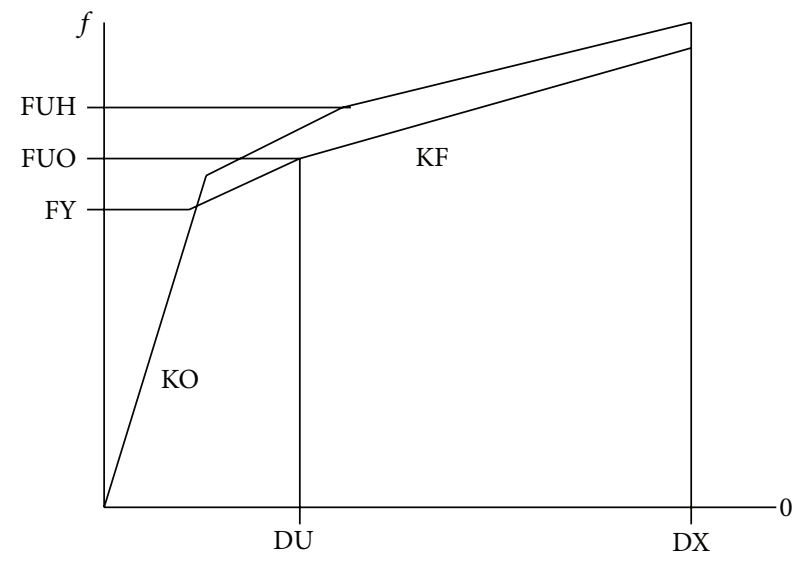

FIGURE 10: Trilinear curve for BRBs.

for braces in cut elements [22]. The low yield point steel braces are used in cut in core wall to mainly achieve more energy dissipation through the early yielding of the brace [43].

5.4. Modelling of Buckling Restrained Braces. A BRB consists of three components, that is, central yielding core brace, ends member connecting the central brace with the pin connection, and pin connection between brace and main structural members. The length of the exterior core brace is $4.5 \mathrm{~m}$, whereas length of the core brace in cut of core wall is $1.8 \mathrm{~m}$. These lengths are in the optimum range of 0.2-0.4 times the total length of the brace. Several advantages such as simple 


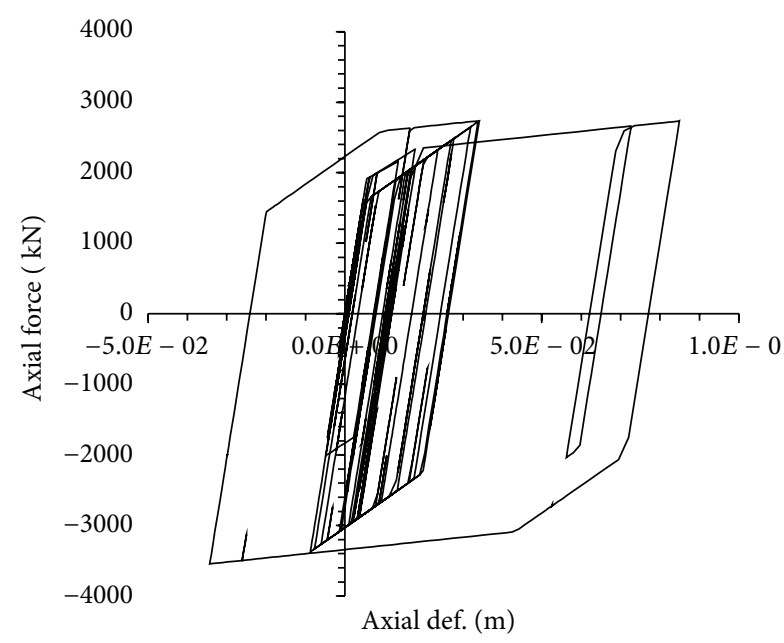

(a)

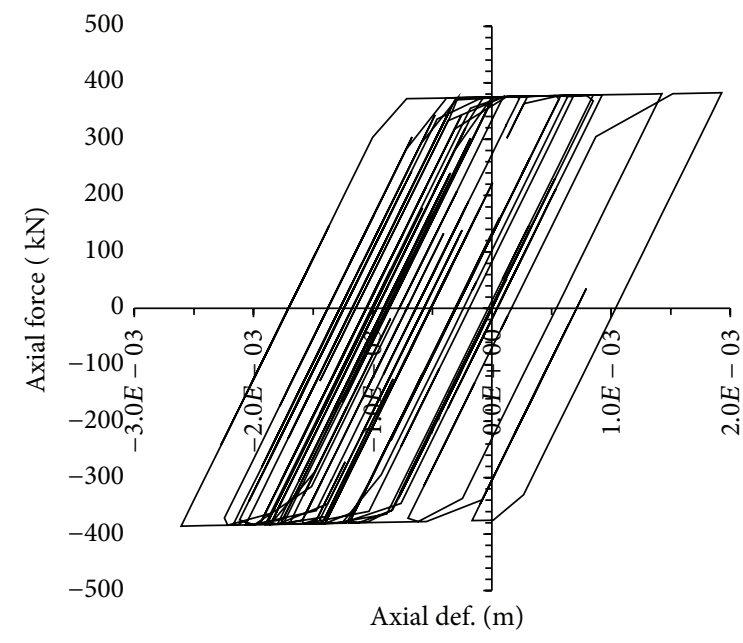

(b)

FIgURE 11: Typical cyclic response of BRBs obtained from the analysis. (a) Exterior brace; (b) interior brace.

replacement, lesser weight, concrete elimination, economy, and easy erection process are associated with reduced length of the core brace [44-50]. BRB has been modelled using the BRB compound component of the Perform-3D. Such member is composed of three components, that is, (1) a BRB basic component for main yielding brace, (2) an elastic bar basic component for member connecting brace with gusset plate, and (3) a stiff end zone which accounts for the gusset plates, and so forth, at both ends of the member.

The positive side (tension) of the trilinear curve to define the force-deformation of the BRBs is shown in Figure 10. It can be seen that, after yielding, there are two lines such as bottom and top line. The bottom line is used to simulate first cyclic load and the top line is used to simulate full strain hardening. The same behavior has been observed in tests like the hysteresis loop which can progressively grow in size. This is sometimes referred to as "isotropic hardening." This leads to the component increase in strength under cyclic load. The negative side of the curve shows a little variation due to difference in the values of compression and tensions. FY, FUO $(\mathrm{FUO}(\mathrm{T})=1.05 \mathrm{FY}, \mathrm{FUO}(\mathrm{C})=1.04 \mathrm{FY})$, and FUH $(\mathrm{FUO}$ $(\mathrm{T})=1.34 \mathrm{FY}, \mathrm{FUO}(\mathrm{C})=1.51 \mathrm{FY})$ are yield strength, strength at first loading cycle, and strength of the core brace after full hardening, respectively. DU (DU $(\mathrm{T})=0.7, \mathrm{DU}(\mathrm{C})=$ $0.7)$ is the deformation at FUO and DX (DX $(T)=0.04 \mathrm{LYC}$, DX $(C)=0.04$ LYC) is the maximum deformation of the brace. LYC is the length of the yielding core. $\mathrm{KO}$ is the Initial stiffness of the core brace and $\mathrm{KF}(=0.02 \mathrm{KO})$ is the slope of third line [42]. The strain hardening properties such as deformation at FUO-FUH average are taken equal to 2 times $(\mathrm{LYC} / 180)$ and deformation at FUH is taken as 3.5 times (LYC/180). The typical force-deformation relationship for exterior (between peripheral columns and core wall) and interior BRB (in cut in core wall) obtained from NLRHA analysis for a particular ground motion is shown in Figures 11 (a) and 11(b), respectively. These figures show that hysteresis loop is similar to the reported Clark et al. 1999 [38] proving that performing BRB element can capture the behaviour appropriately. The size of the elastic bar element is selected such that it can safely carry maximum axial force in brace in elastic range to conform to the capacity design approach. Stiff end zone is few times stiffer than the elastic bar element.

\section{Comparison of the Responses in Different Options and Discussion on the Results}

NLRHA is performed using seven spectrally matched time histories. Different response quantities such as displacement, plastic hinge rotations in coupling beams and core wall, shear deformation angle (story racking shear deformation), bending moment, shear force, and energy demands are obtained from this analysis. The plastic rotations are calculated by multiplying the average curvature of the wall at mid height with the plastic hinge length. The mean value of different quantities obtained from seven ground motions are shown and discussed in following paragraphs.

Shear demands obtained from four options are shown in Figure 12(a). Shear demand pattern and magnitude are similar in all options. Moment demands obtained from four options are shown in Figure 12(b). The moment demand at the base is similar in all four options because this is clipped to the flexural strength of the plastic hinge at the base of the wall. However, it is reduced along the wall height by 30,35 , and $40 \%$ in Option-2, Option-3, and Option-4, respectively, in comparison to that in 1st option. The reduction in moment demand is significant in all options. This will help to avoid reinforcement congestion in the wall near mid height.

Displacement demands obtained from four options are shown in Figure 13(a). Displacement demand pattern is similar for all options. However, displacement demand is reduced along the wall height by 40,40 , and $60 \%$ in Option-2, Option3 , and Option-4, respectively, in comparison to that in 1st option. Racking shear deformation demands obtained from four options are shown in Figure 13(b). The racking shear deformation demand patterns are similar for all four options. However, racking shear deformation demands are reduced 


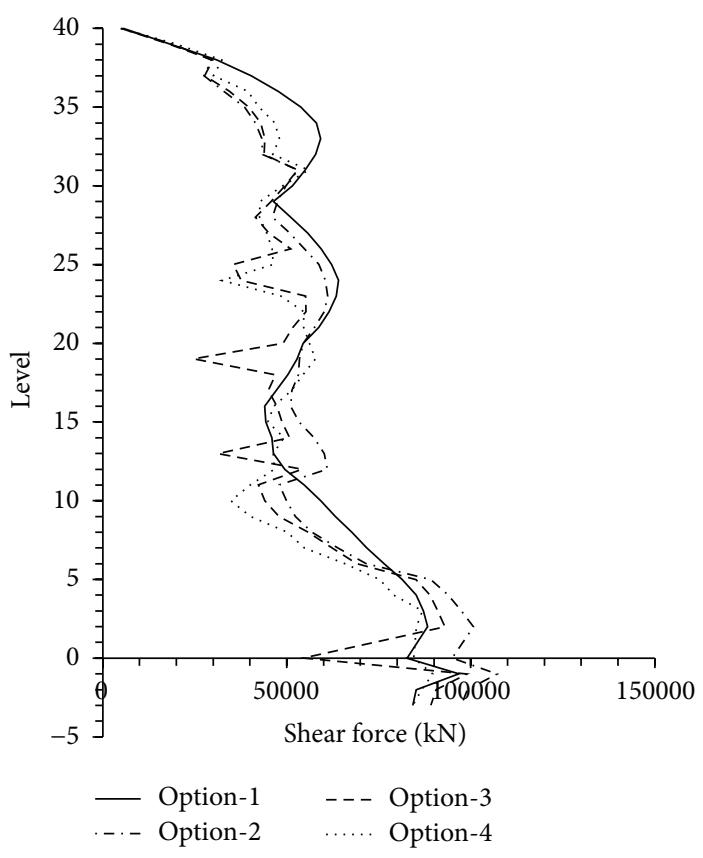

(a)

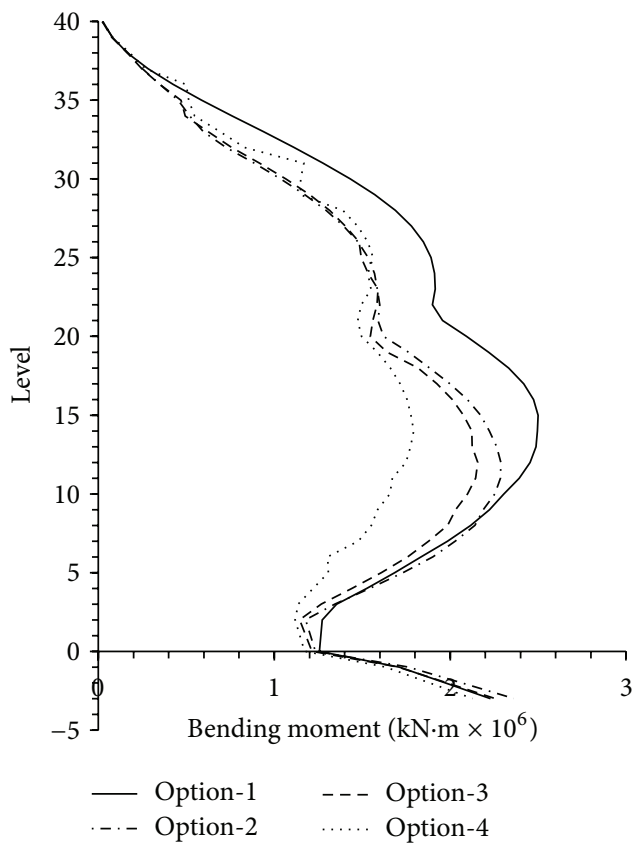

(b)

Figure 12: MCE inelastic shear and moment demands in different options. (a) Shear; (b) moment.

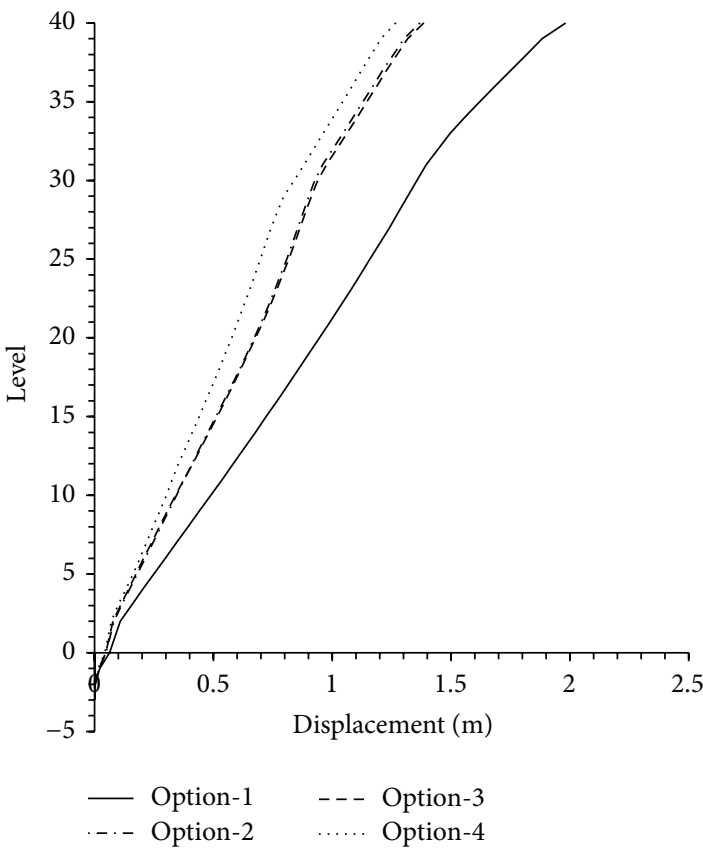

(a)

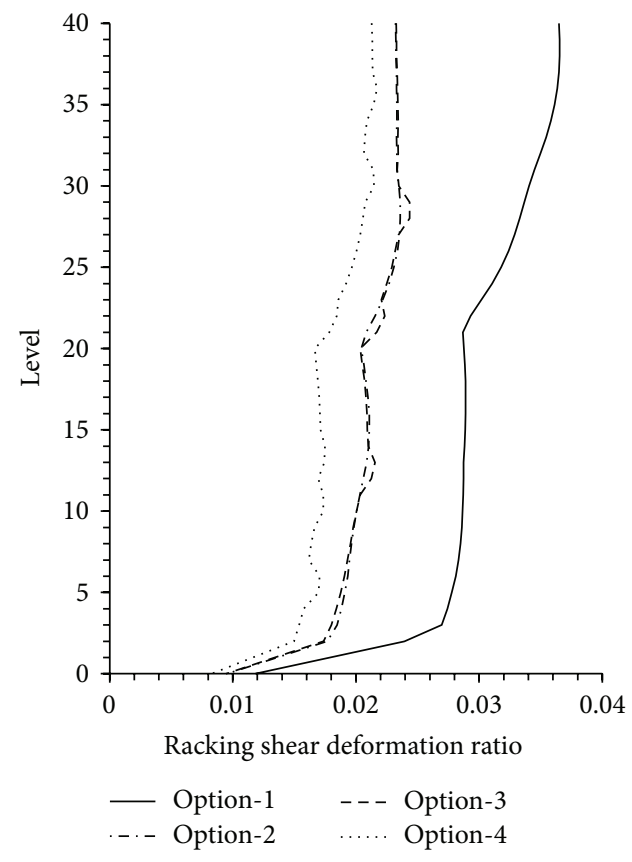

(b)

FIGURE 13: MCE inelastic displacement and racking deformation demands in different options. (a) Displacement; (b) racking shear deformation angle.

along the wall height by 40,40 , and $65 \%$ in Option-2, Option-3, and Option-4, respectively, in comparison to that in 1st option. This is significant reduction. Racking shear deformations of 0.036 in the controlled structures are reduced to 0.023 which is well within the limit of 0.03 set by [29] LATBSDC, 2008, for the MCE level earthquake.
Rotational demands in the core wall at the base level as well as in coupling beams along the height are shown in Figures 14(a) and 14(b), respectively. The rotation demand in the wall is calculated by multiplying the average curvature at the mid height of the inelastic wall element by height of the wall. The comparison shows that the maximum rotational demand 


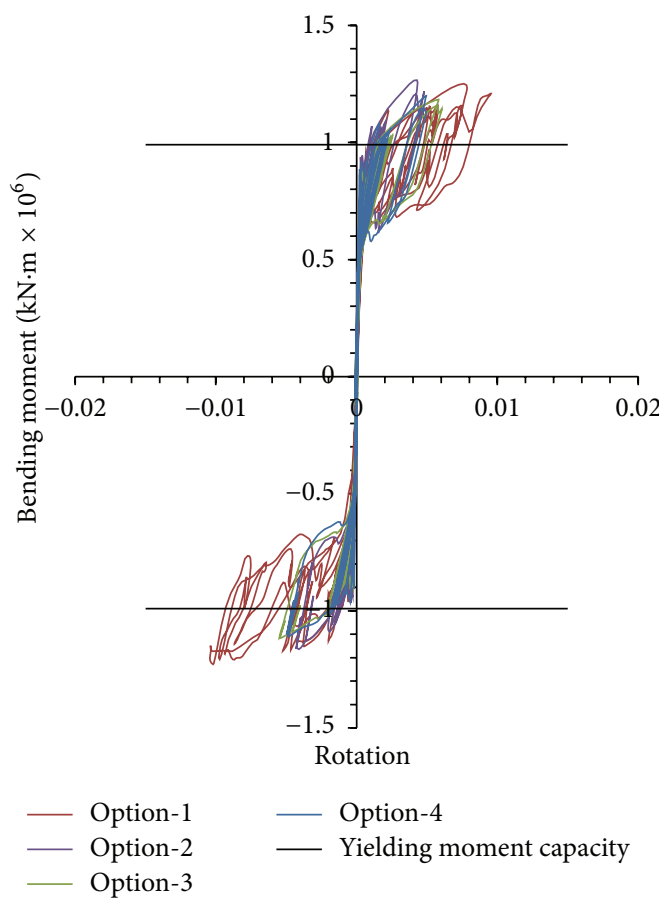

(a)

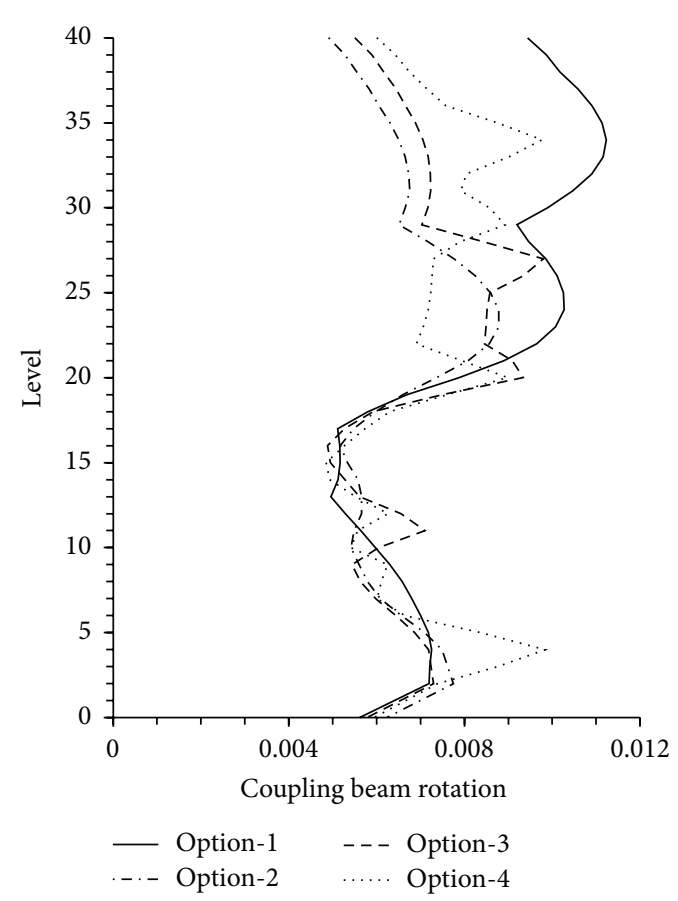

(b)

FIgURE 14: Inelastic rotational demands. (a) Shear walls; (b) coupling beams.

at the base of the wall is reduced by 99,57 , and $93 \%$ in Option2, Option-3, and Option-4, respectively, in comparison to that in 1st option. This is strong indication that damage at the base of the wall shall be reduced to half and consequently extent of repair shall be small and hence cheap in case of severe MCE events such as DBE and MCE level earthquake. The rotational demands in coupling beams are reduced by 52,40 , and $35 \%$, respectively, above the half height level for Option-2, Option-3, and Option-4, respectively, in comparison to 1st option. However, rotation demand remained the same in the lower half portion of the building for all options.

Energy dissipated by core wall, coupling beams, and buckling restrained braces have been compared in Figures 15(a)-15(d), respectively, for Option-1, Option-2, Option3 , and Option-4, respectively. This is energy dissipated in percentage of the total energy demand in the structure. The total energy demand is sum of the kinetic energy, elastic strain energy, energy dissipated by elastic modal damping, and energy dissipation by damage in structural elements such as core wall, coupling beams, and BRBs. About 83\%, 92\%, $92 \%$, and $90 \%$ energy have been dissipated by elastic modal and inelastic damping in Option-1 to Option-4, respectively. The energy dissipation by modal elastic damping to the total energy demands is $50 \%, 37 \%, 35 \%$, and $33 \%$, respectively, in Option-1 to Option-4, respectively. The energy dissipation by core wall at the base to the total energy demands is $22 \%, 6 \%$, $6 \%$, and $6 \%$ in Option- 1 to Option-4, respectively. The energy dissipation by coupling beams to the total energy demands is approximately $10 \%, 4 \%, 5 \%$, and $6 \%$ in Option- 1 to Option4 , respectively. The energy dissipation by BRBs to the total energy demands is $0 \%, 45 \%, 45 \%$, and $45 \%$, respectively, in Option-1 to Option-4.

\section{Effects of BRBs on Axial Loads, Shear, and Moment of Columns and Permanent Deformation due to BRBs Plastification}

Effects of BRBs on axial loads of columns and permanent deformation due to BRBs plastification have been discussed in this section. The axial load envelope in a typical column for Options-1-4 is shown in the Figure 16. The magnitude of axial load is same for Options-2-4 (with BRBs) and is twice than that in Option-1 (controlled structure). This is due to the outrigger effect created by the connection of columns and core wall through BRBs. Some core wall moment has been resisted by the development of axial push-pull in the columns. Furthermore, the shape of the axial load envelope is smooth in case of Option-1, whereas it is jagged at the locations of the BRBs for Options-2-4. The moment envelope and shear envelope for one typical column are shown in Figures 17(a) and 17(b), respectively. It shows that moment and shear have been reduced at the ground level in Options2-4 in comparison to Option-1, whereas these remain almost the same at upper portions. The extra moment and shear at the ground level in Options-1-4 is due to the transfer of moment and shear to the columns when core wall yields.

To better understand the permanent deformation in the structure due to BRBs plastification, cyclic pushover analysis in first mode is performed using target displacement obtained from NLTHA for all cases. The cyclic base shear versus top 


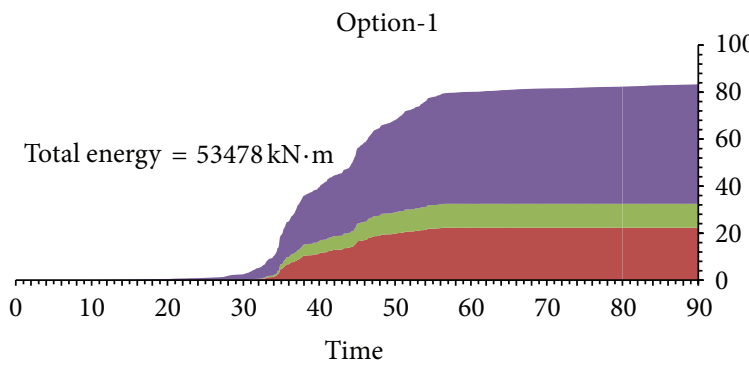

- Dissipated energy by elastic viscous damping

- Dissipated inelastic energy by coupling beams

- Dissipated inelastic energy by shear walls

- Dissipated inelastic energy by BRBs

(a)

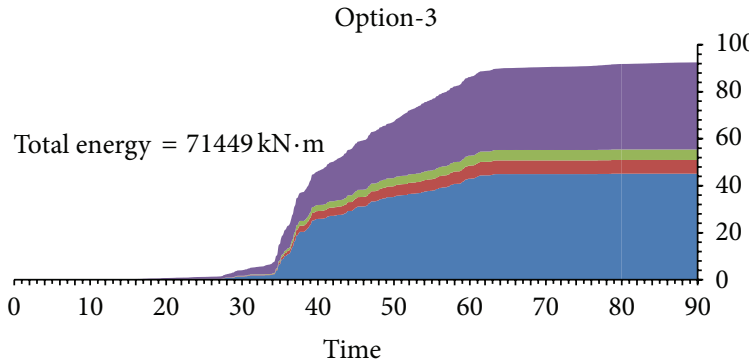

- Dissipated energy by elastic viscous damping

- Dissipated inelastic energy by coupling beams

- Dissipated inelastic energy by shear walls

- Dissipated inelastic energy by BRBs

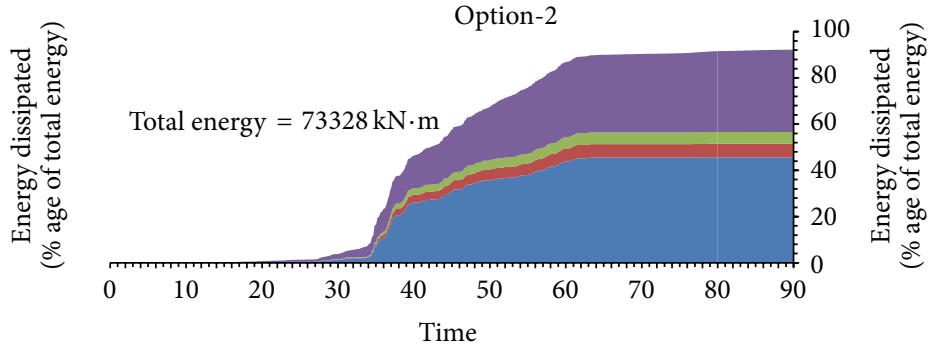

- Dissipated energy by elastic viscous damping

- Dissipated inelastic energy by coupling beams

- Dissipated inelastic energy by shear walls

- Dissipated inelastic energy by BRBs

(b)

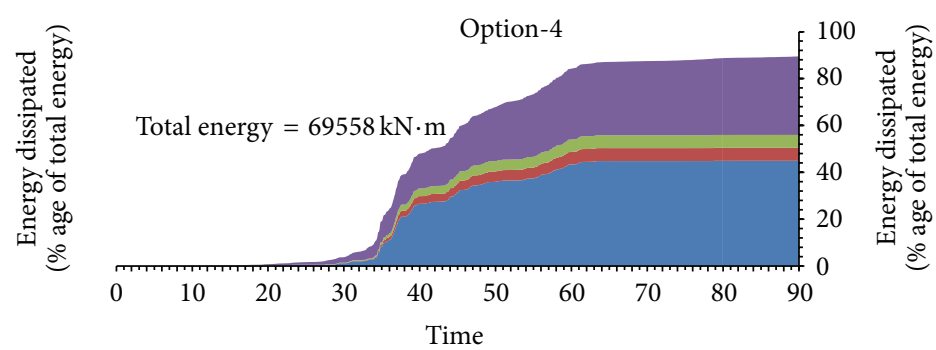

- Dissipated energy by elastic viscous damping

- Dissipated inelastic energy by coupling beams

- Dissipated inelastic energy by shear walls

- Dissipated inelastic energy by BRBs

(c)

(d)

FIGURE 15: Inelastic energy demands in structural components. (a) to (d) For Option-1 to Option-4, respectively.

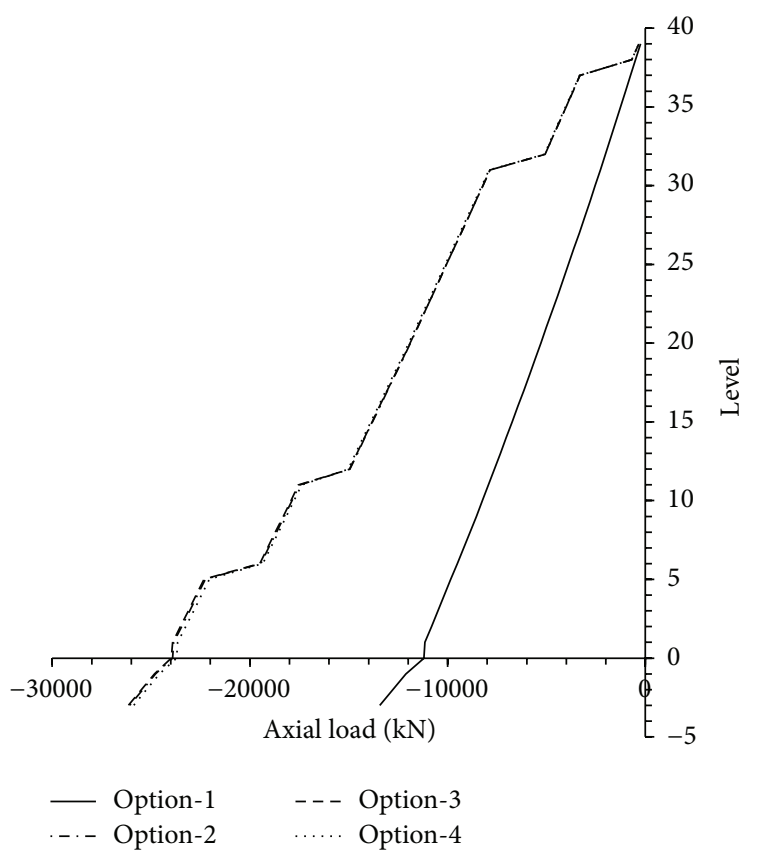

FIgURE 16: Axial load envelope in one typical column. 

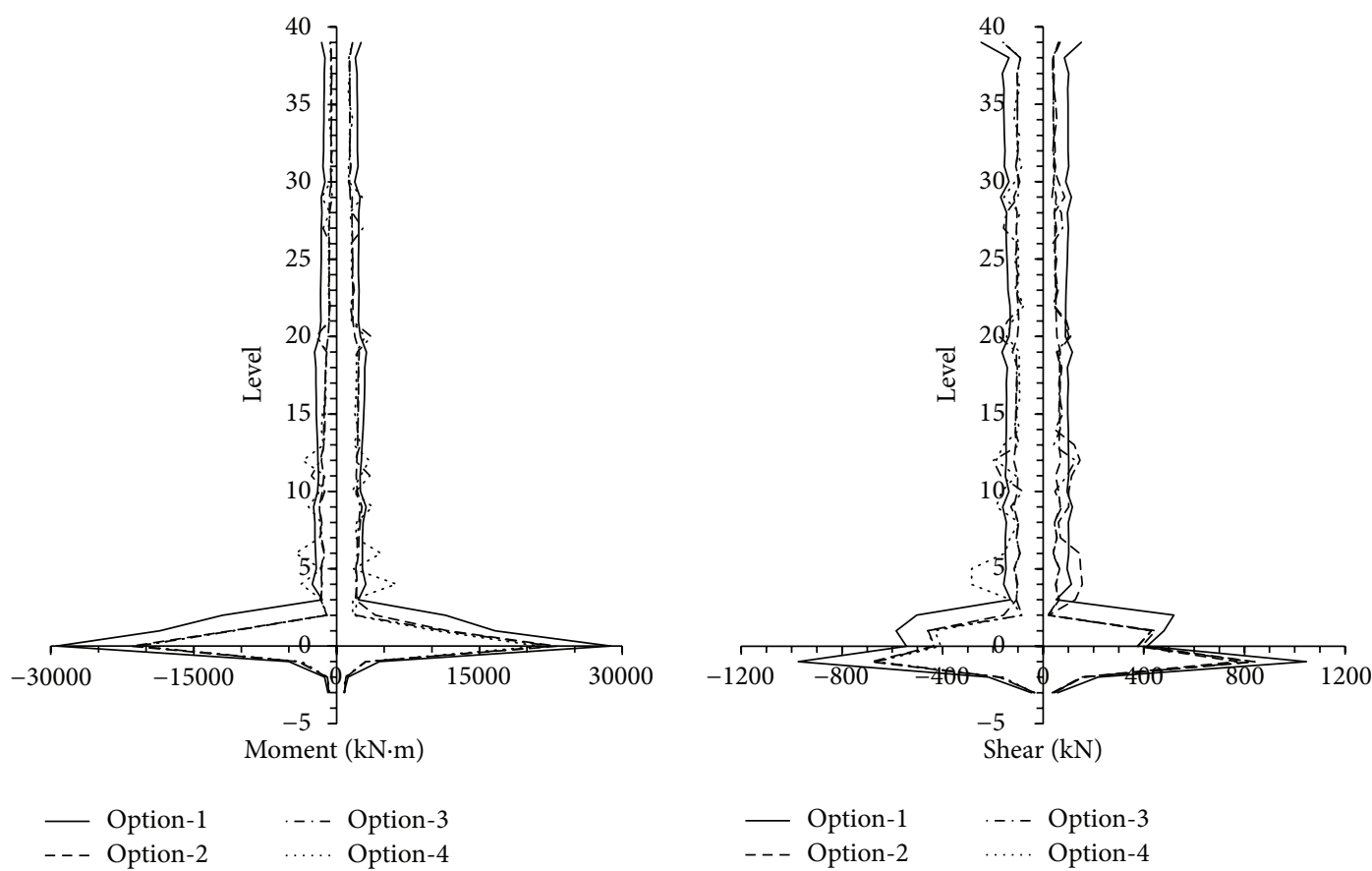

FIGURE 17: Moment and shear envelope in one typical column.

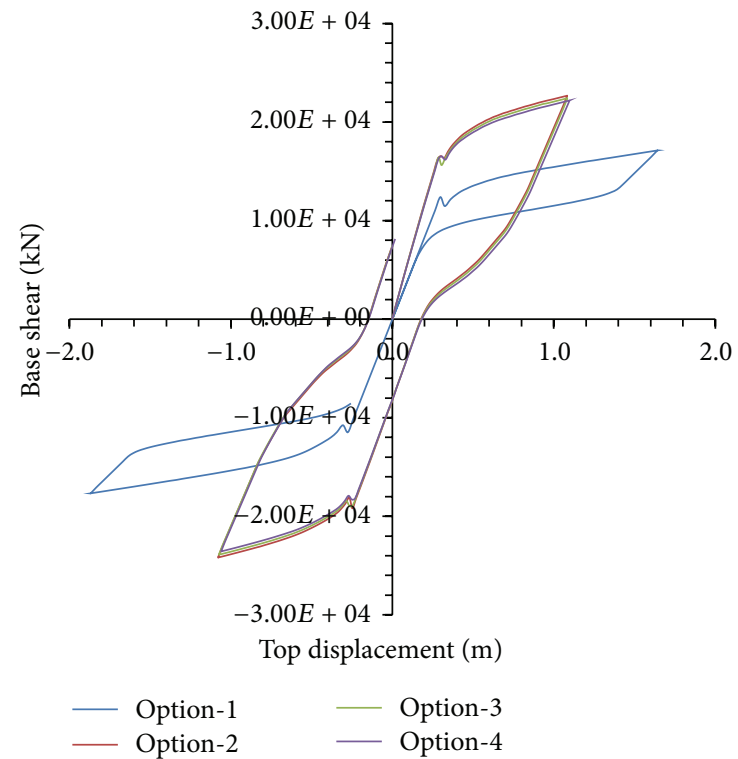

Figure 18: Base shear versus top displacement relationship in first mode load pattern.

displacement is compared in Figure 18. It can be seen that this curve is flag shaped for Option-1, whereas it is bilinear pinching type in Options-2-4. There is no permanent deformation in controlled structure and flag shaped hysteresis behaviour is observed. The same behaviour was observed during test conducted on a large-scale model of a concrete shear wall from the core of a high-rise building in the study of Adebar et al. [27]. The combination of low percentage of vertical reinforcement and large axial compression force due to gravity loads (axial force/(concrete 28 days cylinder strength $\times$ gross area of wall) $>0.1$ ) caused the flexural cracks to close when the lateral load was removed. In Options-2-4, small permanent deformation (residual displacement) is observed. This is because of the plastification of BRBs as well as transfer of the moment demand from shear wall to columns in the form of axial push-pull.

\section{Conclusions}

(i) In this study, different options of location of BRBs are investigated for a 40 -story case study building. The locations of BRBs are identified based on the DBE elastic racking shear deformation and shear and bending moment demands in dominant 2 nd and $3 \mathrm{rd}$ modes. NLRHA is then performed for seven sets of spectrally matched target time histories and results are compared for different options.

(ii) In all options, shear force demands, bending moment at mid height, displacement demand, racking shear deformation demand, and rotation demand in coupling beams are reduced by $10 \%, 45 \%, 45 \%, 45 \%$, and $40 \%$, respectively, in comparison to the controlled structure.

(iii) Rotational demand in the core wall at base level is reduced by $99 \%, 57 \%$, and $93 \%$ in Option-2, Option3 , and Option-4, respectively, in comparison to Option-1. Whereas, energy dissipated by the core wall is reduced by around $250 \%$ in the core wall in comparison to the controlled structure. Rotational demand and energy dissipation are measure of damage in the core wall. Thus damage can be significantly reduced by installation of BRBs. 
(iv) All BRBs options are effective for bending moment reduction at mid height, displacement and racking shear deformation demands along the wall height, and rotation demand at the base of the wall and in coupling beams above the mid height of the building. However, Option-4 in which BRBs are installed between peripheral columns and central core wall and cut in shear walls based on the maximum shear force and bending moment leads to the highest reduction. This is because of the early yielding of the interior braces.

(v) This work is equally important for academia and practising engineers especially those working in the field of performance based design of the high-rise buildings in the commercial consultancy. This will help them to locate BRBs at appropriate locations while designing their buildings in an optimal way.

\section{Conflict of Interests}

The authors declare that there is no conflict of interests regarding the publication of this paper.

\section{References}

[1] International Conference of Building Officials, Uniform Building Code, vol. 2, International Conference of Building Officials, Whittier, Calif, USA, 1997.

[2] J. Maffei and N. Yuen, "Seismic performance and design requirements for high rise buildings," Structural Magazine, pp. 28-32, 2007.

[3] J. P. Moehle, "Performance-based seismic design of tall buildings in the U.S.," in Proceedings of the 14th World Conference on Earthquake Engineering, Beijing, China, October 2008.

[4] CEN EC8, Design of Structures for Earthquake Resistance, European Committee for Standardization, Brussels, Belgium, 2004.

[5] NZS 3101: Part 1:2006, Concrete Structures Standards, New Zealand, Standards New Zealand, Wellington, New Zealand, 2006.

[6] T. Paulay and M. J. N. Priestley, Seismic Design of Reinforced Concrete and Masonry Buildings, Wiley, Hoboken, NJ, USA, 1992.

[7] M. Panagiotou, J. I. Restrepo, and J. P. Conte, "Shake table test of a 7-story full scale reinforced concrete structural wall building slice phase I: rectangular wall," Report SSRP 07-07, Department of Structural Engineering, University of California, San Diego, San Diego, Calif, USA, 2007.

[8] Canadian Standard Association, CSA Standard A23.3-04, Design of Concrete Structures, Canadian Standard Association, Rexdale, Canada, 2005.

[9] R. Klemencic, J. A. Fry, J. D. Hooper, and B. G. Morgen, "Performance-based design of ductile concrete core wall buildings-issues to consider before detailed analysis," The Structural Design of Tall and Special Buildings, vol. 16, no. 5, pp. 599-614, 2007.

[10] R. Klemencic, "Performance based seismic design-rising," Structural Magazine, 2008, http://www.structuremag.org/ wp-content/uploads/2014/08/C-StructuralPractices-KlemencicJune081.pdf.
[11] A. Zekioglu, M. Willford, L. Jin, and M. Melek, "Case study using the Los Angeles tall buildings structural design council guidelines: 40-storey concrete core wall building," Structural Design of Tall and Special Buildings, vol. 16, no. 5, pp. 583-597, 2007.

[12] B. R. Rad and P. Adebar, "Dynamic shear amplification in high-rise concrete walls: effect of multiple flexural hinges and shear cracking," in Proceedings of the 14th World Conference on Earthquake Engineering, Beijing, China, October 2008.

[13] M. Panagiotou and J. I. Restrepo, "Dual-plastic hinge design concept for reducing higher-mode effects on high-rise cantilever wall buildings," Earthquake Engineering and Structural Dynamics, vol. 38, no. 12, pp. 1359-1380, 2009.

[14] M. Ahmed and P. Warnitchai, "Reduction of inelastic seismic demands by inducing plastic hinges at effective locations," in Proceedings of the 3rd Asian Conference on Earthquake Engineering (ACEE '10), Bangkok, Thailand, December 2010.

[15] A. Munir and P. Warnitchai, "The cause of unproportionately large higher mode contributions in the inelastic seismic responses of high-rise core-wall buildings," Earthquake Engineering \& Structural Dynamics, vol. 41, no. 15, pp. 2195-2214, 2012.

[16] A. Munir and P. Warnitchai, "Optimal reduction of inelastic seismic demands in high-rise reinforced concrete core wall buildings using energy-dissipating devices," Structural Design of Tall and Special Buildings, vol. 22, no. 7, pp. 543-568, 2013.

[17] M. C. Constantinou and M. D. Symans, "Experimental and analytical investigation of seismic response of structures with supplemental fluid viscous dampers," NCEER Reports 92-0032, State University of New York at Buffalo, Buffalo, NY, USA, 1992.

[18] A. S. Whittaker, V. V. Bertero, C. L. Thompson, and L. J. Alonso, "Seismic testing of steel plate energy dissipation devices," Earthquake Spectra, vol. 7, no. 4, pp. 563-604, 1991.

[19] G. W. Housner, L. A. Bergman, T. K. Caughey et al., "Structural control: past, present, and future," Journal of Engineering Mechanics, vol. 123, no. 9, pp. 897-971, 1997.

[20] M. D. Symans, F. A. Charney, A. S. Whittaker et al., "Energy dissipation systems for seismic applications: current practice and recent developments," Journal of Structural Engineering, vol. 134, no. 1, pp. 3-21, 2008.

[21] C. J. Black, N. Makris, and I. D. Aiken, "Component testing, seismic evaluation and characterization of buckling-restrained braces," Journal of Structural Engineering, vol. 130, no. 6, pp. 880-894, 2004.

[22] S. Keten, A performance based approach for seismic design with hysteretic dampers [M.S. thesis], Massachusetts Institute of Technology (MIT), 2006, http://dspace.mit.edu/bitstream/handle/1721.1/34595/71252112-MIT.pdf?sequence=2.

[23] N. Anwar, J. A. Sy, T. H. Aung, and D. Rayamajhi, "First application of buckling restraint brace system in Philippines in a 50-story building with ductile core wall and PT slab system," in Proceedings of the 9th International Conference on Urban Earthquake Engineering and the 4th Asia Conference on Earthquake Engineering, Tokyo Institute of Technology, Tokyo, Japan, March 2012.

[24] Computers and Structures Inc, ETABS Extended 3D Analysis of Building Systems Software, Nonlinear Version 9.0.0, Computers and Structures Inc, Berkeley, Calif, USA, 2005.

[25] Computers and Structures, Perform 3D, Nonlinear Analysis and Performance Assessment for 3D Structures User Guide, Version 4, Computers and Structures, Berkeley, Calif, USA, 2006. 
[26] J. W. Wallace and J. P. Moehle, "Ductility and detailing requirements of bearing wall buildings," Journal of Structural Engineering, vol. 118, no. 6, pp. 1625-1644, 1992.

[27] P. Adebar, A. M. M. Ibrahim, and M. Bryson, "Test of high-rise core wall: effective stiffness for seismic analysis," ACI Structural Journal, vol. 104, no. 5, pp. 549-559, 2007.

[28] FEMA, "Prestandard and commentary for the seismic rehabilitation of buildings," FEMA 356, Federal Emergency Management Agency, Washington, DC, USA, 2000.

[29] LATBDSC, An Alternative Procedure for Seismic Analysis and Design of Tall Buildings Located in Los Angeles Region, A Consensus Document, Los Angeles Tall Buildings and Structural Design Council, 2008.

[30] PEER NGA Data Base, Pacific Earthquake Engineering Research (PEER), University of California, Berkeley, Calif, USA, 2005, http://peer.berkeley.edu/nga/.

[31] COSMOS Data Base, "Consortium of organization for strongmotion observation systems," Tech. Rep., University of California, Berkeley, Calif, USA, 1999-2007, http://www.cosmos-eq .org/scripts/default.plx.

[32] K. Lilhanand and W. S. Tseng, "Development and application of realistic earthquake time histories compatible with multiple damping design spectra," in Proceedings of the 9th World Conference on Earthquake Engineering, Tokyo, Japan, August 1988.

[33] J. Hancock, J. Watson-Lamprey, N. A. Abrahamson et al., "An improved method of matching response spectra of recorded earthquake ground motion using wavelets," Journal of Earthquake Engineering, vol. 10, no. 1, pp. 67-89, 2006.

[34] J. B. Mander, M. J. N. Priestley, and R. Park, "Theoretical stress-strain model for confined concrete," Journal of Structural Engineering New York, vol. 114, no. 8, pp. 1804-1826, 1988.

[35] CTBUH Seismic Working Group, CTBUH Recommendations for the Seismic Design of High-Rise Buildings, A Consensus Document, 2008.

[36] N. Satake, K.-I. Suda, T. Arakawa, A. Sasaki, and Y. Tamura, "Damping evaluation using full-scale data of buildings in Japan," Journal of Structural Engineering, vol. 129, no. 4, pp. 470477, 2003.

[37] Q. Xie, "State of the art of buckling-restrained braces in Asia," Journal of Constructional Steel Research, vol. 61, no. 6, pp. 727748, 2005.

[38] P. Clark, K. Kasai, I. Aiken, E. Ko, and I. Kimura, "Design procedures for buildings incorporating hysteretic energy dissipating devices," in Proceedings of the 68th Annual Convention, Structural Engineers Association of California, Santa Barbara, Calif, USA, October 1999.

[39] D. Vafaei and R. Eskandari, "Seismic response of mega buckling-restrained braces subjected to fling-step and forwarddirectivity near-fault ground motions," Structural Design of Tall and Special Buildings, vol. 24, no. 9, pp. 672-686, 2015.

[40] L. Di Sarno and A. S. Elnashai, "Bracing systems for seismic retrofitting of steel frames," Journal of Constructional Steel Research, vol. 65, no. 2, pp. 452-465, 2009.

[41] A. Dutta and R. O. Hamburger, "Case study of A 40-Storey buckling-restrained braced frame building located in Los Angeles," The Structural Design of Tall and Special Buildings, vol. 19, no. 1-2, pp. 77-93, 2010.

[42] Rutherford \& Chekene, "Perform nonlinear component modelling of star seismic powercat BRBs," Report to Star Seismic LLC, Star Seismic, LLC, 2011.
[43] P. Dusicka, A. M. Itani, and I. G. Buckle, "Cyclic response of plate steels under large inelastic strains," Journal of Constructional Steel Research, vol. 63, no. 2, pp. 156-164, 2007.

[44] S. A. Razavi, M. E. Shemshadian, S. R. Mirghaderi, and S. Ahlehagh, "Seismic design of buckling restrained braced frames with reduced core length," in Proceedings of the The Structural Engineers World Congress, Cernobbio, Italy, 2011.

[45] S. A. Razavi, S. R. Mirghaderi, A. Hosseini, and M. E. Shemshadian, "Reduced length buckling restrained brace using steel plates as restraining segment," in Proceedings of the 15th World Conference on Earthquake Engineering, Lisboa, Purtagal, September 2012.

[46] M. E. Shemshadian, S. A. Razavi, S. R. Mirghaderi, A. Hosseini, and M. K. Mohammadi, "The advantages of reducing the length of yielding segment in seismic performance of buckling restrained braced frames," in Proceedings of the 6th International Conference of Seismology and Earthquake Engineering, Tehran, Iran, 2011.

[47] N. Ma, B. Wu, J. Zhao, H. Li, J. Ou, and W. Yang, "Full scale test of all-steel buckling restrained braces," in Proceedings of the 14th World Conference on Earthquake Engineering, Beijing, China, October 2008.

[48] L. Di Sarno and G. Manfredi, "Seismic retrofitting of existing RC frames with buckling restrained braces," in Proceedings of the Improving the Seismic Performance of Existing Buildings and Other Structures, pp. 741-752, San Francisco, Calif, USA, December 2009.

[49] S. Ahlehagh, Improvement of the special concentrically braced steel frames behaviour by employing balanced braces [M.S. thesis], University of Tehran, Tehran, Iran, 2008.

[50] R. Tremblay, P. Bolduc, R. Neville, and R. DeVall, "Seismic testing and performance of buckling-restrained bracing systems," Canadian Journal of Civil Engineering, vol. 33, no. 2, pp. 183-198, 2006. 


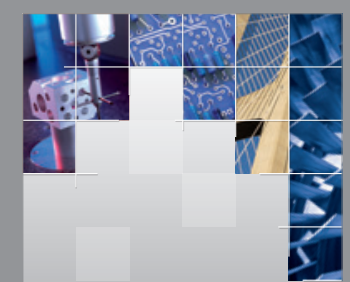

\section{Enfincering}
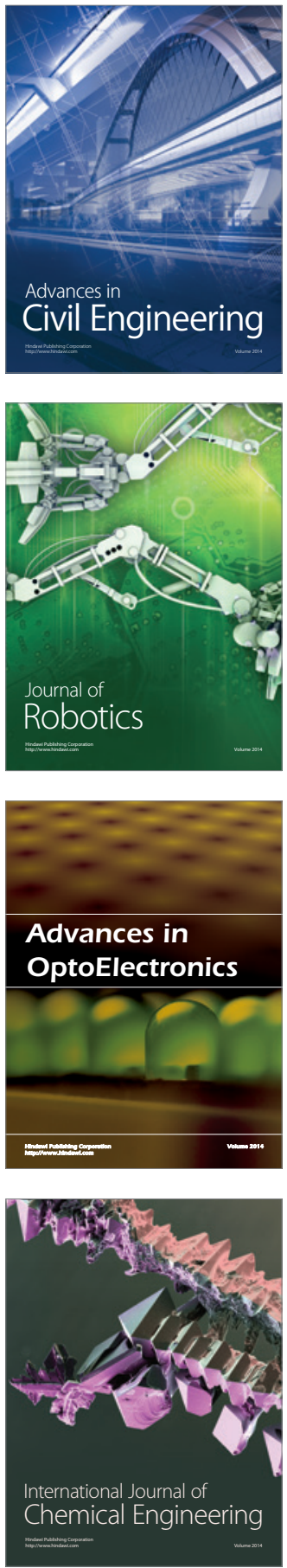

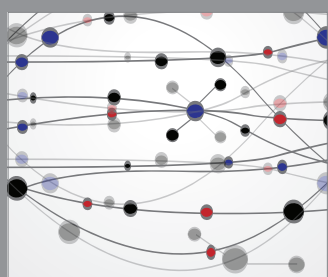

The Scientific World Journal

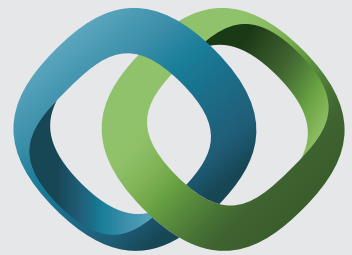

\section{Hindawi}

Submit your manuscripts at

http://www.hindawi.com
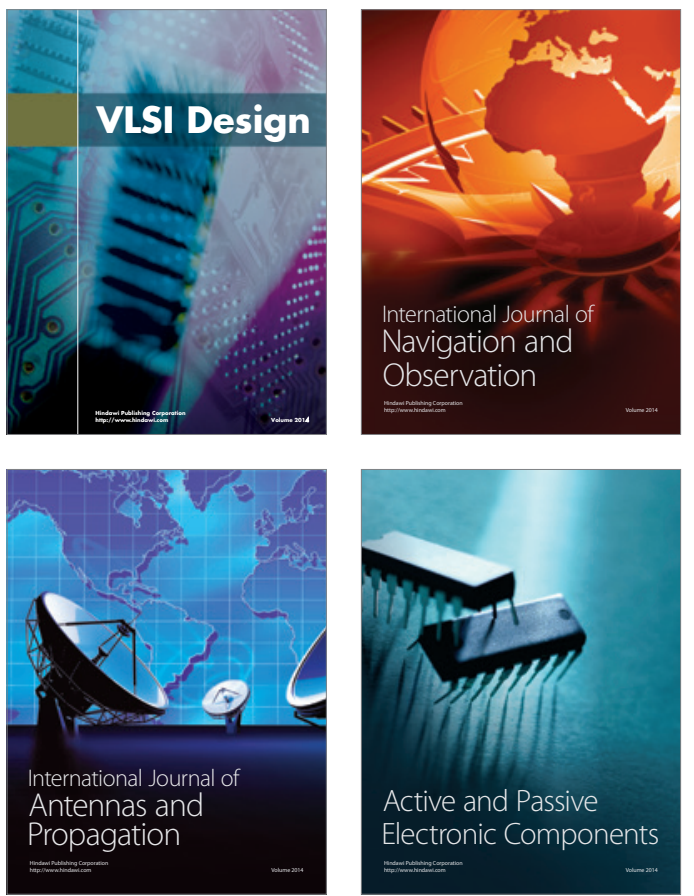
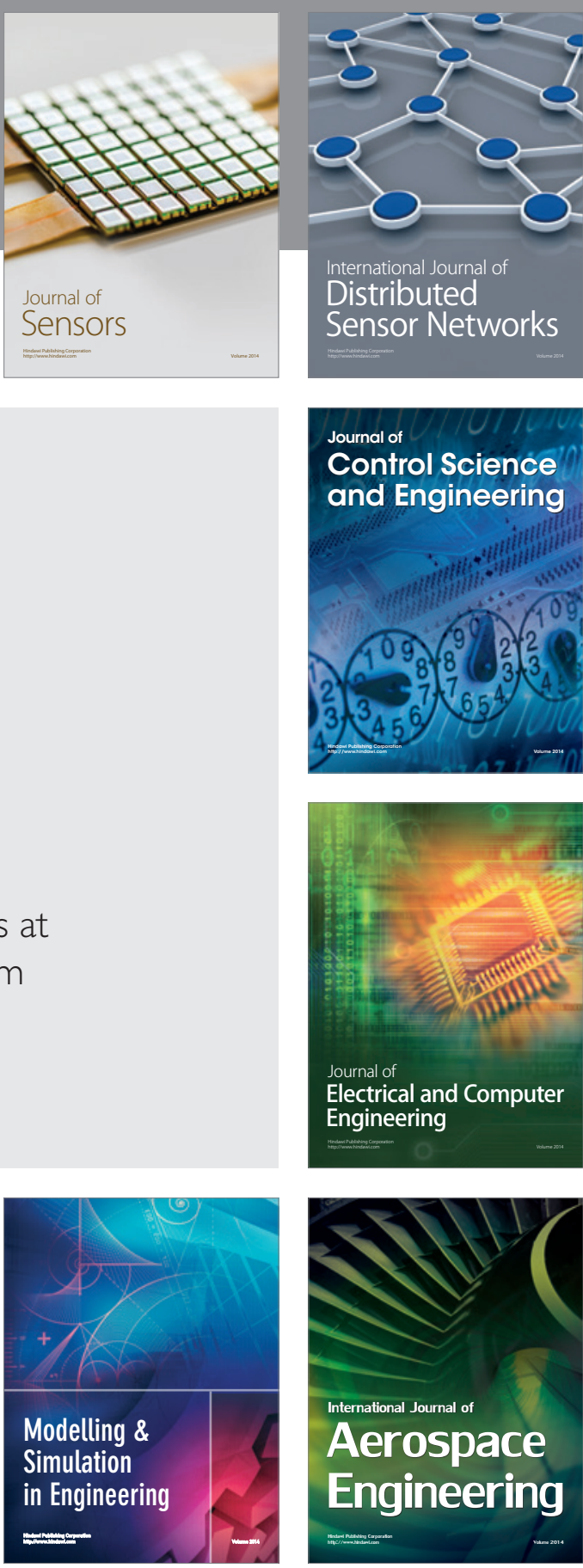

International Journal of

Distributed

Sensor Networks

Journal of

Control Science

and Engineering
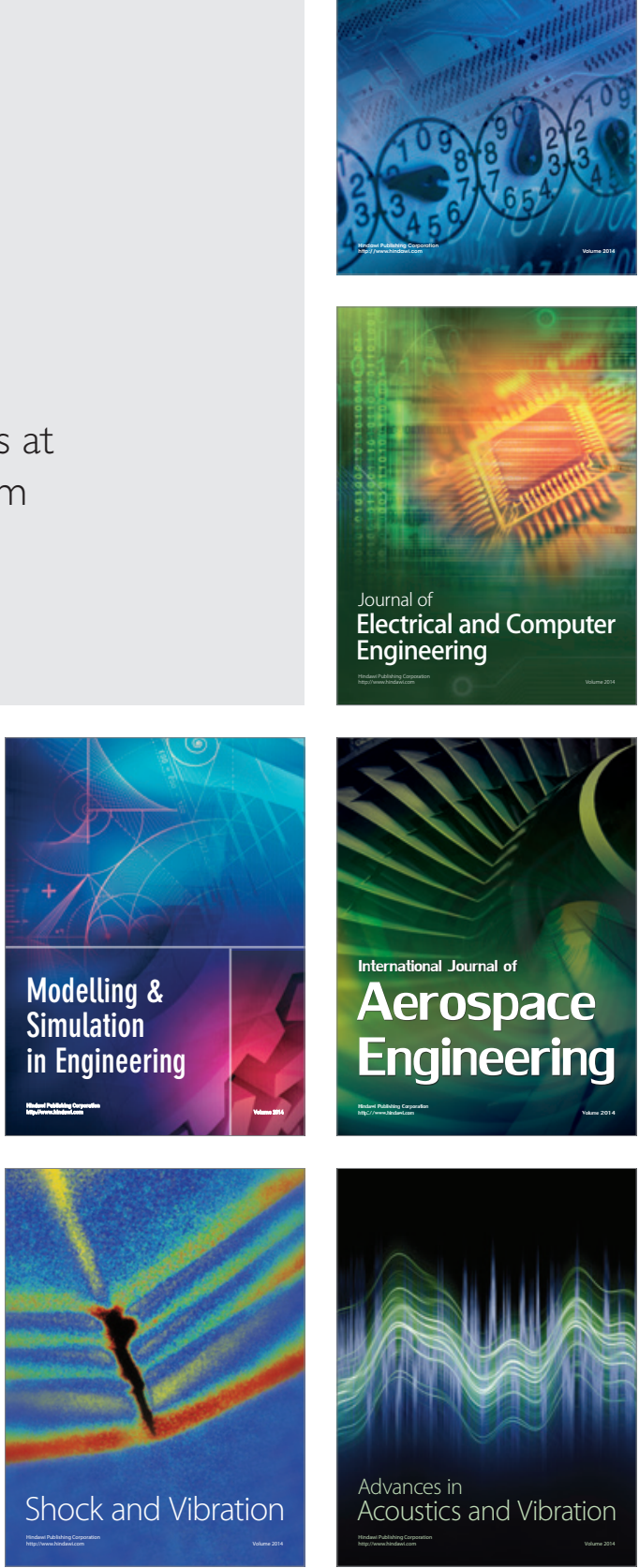